TITLE:

\title{
ON EUCHIRELLA (COPEPODA, CALANOIDA) COLLECTED CHIEFLY BY THE U. S. STEAMER ALBATROSS FROM THE PACIFIC OCEAN
}

\section{$\operatorname{AUTHOR}(\mathrm{S}):$}

Tanaka, Otohiko; Omori, Makoto

\section{CITATION:}

Tanaka, Otohiko ...[et al]. ON EUCHIRELLA (COPEPODA, CALANOIDA) COLLECTED CHIEFLY BY THE U. S. STEAMER ALBATROSS FROM THE PACIFIC OCEAN. PUBLICATIONS OF THE SETO MARINE BIOLOGICAL LABORATORY 1969, 17(1): 33-65

ISSUE DATE:

1969-05-30

URL:

http://hdl.handle.net/2433/175567

RIGHT: 


\title{
ON EUCHIRELLA (COPEPODA, CALANOIDA) \\ COLLECTED CHIEFLY BY THE U.S. STEAMER ALBATROSS FROM THE PACIFIC OCEAN
}

\author{
OтонIко TANAKA' ${ }^{\text {I) }}$ and MAKoto OMORI ${ }^{2)}$
}

With 10 Text-figures

At least 18 species of Euchirella have been reported from the Pacific and Indian Oceans. They are Euchirella amoena Giesbrecht, E. bella Giesbrecht, E. bitumida With, E. curticauda Giesbrecht, E. formosa Vervoort, E. galeata Giesbrecht, $E$. grandicornis Wilson, E. indica Vervoort, E. intermedia With, E. maxima Wolfenden, E. messinensis (Claus), E. orientalis Seweld, E. pulchra (Lubbock), E. rostrata (Claus), E. propria Esterly, E. tanseii Omori, E. truncata Esterly, and E. venusta Geisbrecht. However, as some species have been described inadequately, we felt it necessary to correct specific determination of the genus Euchirella.

In the course of studies on Euchirella in the Izu region, we asked Drs. T.E. Bowman of the Smithsonian Institution, G. D. Grice of the Woods Hole Oceanographic Institution, and W. VERVOORT of the Rijksmuseum van Natuurlijke Historie, for the loan of specimens of $E$. indica and $E$. messinensis. They were so kind enough to send us the specimens collected from several parts of the Pacific and Atlantic Oceans. During the examination of the materials from the Smithsonian Institution (C.B. WiLson's collections), we found that the vials labelled as $E$. messinensis contained a number of other species of Euchirella. Accordingly, we requested again from Dr. Bowman the loan of other samples of Euchirella taken by the U.S. STEAmer Albatross in the Pacific Ocean. He sent us the materials including the specimens collected by the $\mathrm{R} / \mathrm{V}$ Carnegie. These specimens had previously been identified by Dr. G. O. SARs or Dr. G. B. Wilson, and reported by the latter $(1942,1950)$. As a result of re-examination of a total of 487 specimens of the WiLson Collection contained in 40 vials, the following copepods were found: 14 species of Euchirella, 1 species of Neocalanus, 1 species of Undinula, 1 species of Gaidius, 2 species of Gaetanus, 2 species of Chirundina, 1 species of Chirundinella, 2 species of Undeuchaeta, 1 species of Euchaeta, 3 species of Scottocalanus, 1 species of Lophothrix, 1 species of Scaphocalanus, and 1 species of the new genus Wilsonidius (Appendix-table).

1) 60 Sangenchaya-machi, Setagaya, Tokyo

2) Ocean Research Institute, University of Tokyo, Nakano, Tokyo

Publ. Seto Mar. Biol. Lab., XVII (1), 33-65, $1969 . \quad$ (Article 3) 
The present paper deals with the taxonomy of Euchirella collected chiefly by the R/V Albatross in the Pacific Ocean. Besides the description of a new species, redescriptions and revisions are given for some other species. In writing the diagnosis, the specimens collected from the Izu region by the R/V Tansei Maru of the Ocean Research Institute, University of Tokyo, were often used and they were compared with the Albatross specimens. The sampling data for the Tansei Maru specimens is given by TANAKA and OMORI (1968). All of the specimens borrowed have been returned to the institutions indicated. The Tansei Maru specimens are deposited in the Ocean Research Institute. A paper regarding the remaining species of the WiLson Collection will be published in the near future.

We wish to express our appreciation to Drs. T. E. Bowman, G. D. Grice, and W. Vervoort who permitted us to examine their important specimens. Dr. Bowman kindly read the manuscript and gave us helpful criticism. Thanks are also due to Prof. R. Marumo of the Ocean Research Institute for his encouragement given during the course of the study.

\section{Euchirella acuta, new species}

(Fig. 1, a-n)

Occurrence: U.S.N.M. No. 122748, 2 ad. $\subsetneq$ (paratypes), U.S.N.M. No. 122747, 1 ad. $\delta$ (holotype); U.S.N.M. No. 120661, 3 ad. $\partial$ (paratypes).

Descriptive notes: Female, 4.70 and $4.78 \mathrm{~mm}$ (paratypes). The cephalothorax and abdomen are in the proportional lengths as 80 to 20 . The cephalothorax is 2.2 times as long as wide. The head is fused with the lst thoracic segment, as are the 4 th and 5 th thoracic segment. The frontal margin of the head is broadly rounded in lateral view. The lateral margin of the last thoracic segment is round. The rostrum is slender and directed downwards.

The abdomen is 4-jointed; the segments have the following proportional lengths :

\begin{tabular}{lrrrrr} 
segment & $1-2$ & 3 & 4 & 5 & furca \\
\cline { 2 - 5 } & 12 & 9 & 6 & 17
\end{tabular}$=100$

The genital segment is as long as wide; the lateral margins are almost symmetrical; the dorsal distal margin is produced posteriorly and slightly overlaps the following segment; the genital area is produced below. The 3rd and 4th segments are each fringed with fine teeth on the distal margin. The furcal rami are slightly wider than long: the distal margin of each ramus is furnished with 4 long setae, an appendicular seta, and a small lateral spine.

The lst antenna is 23-jointed, and extends to the distal margin of the furca: it 


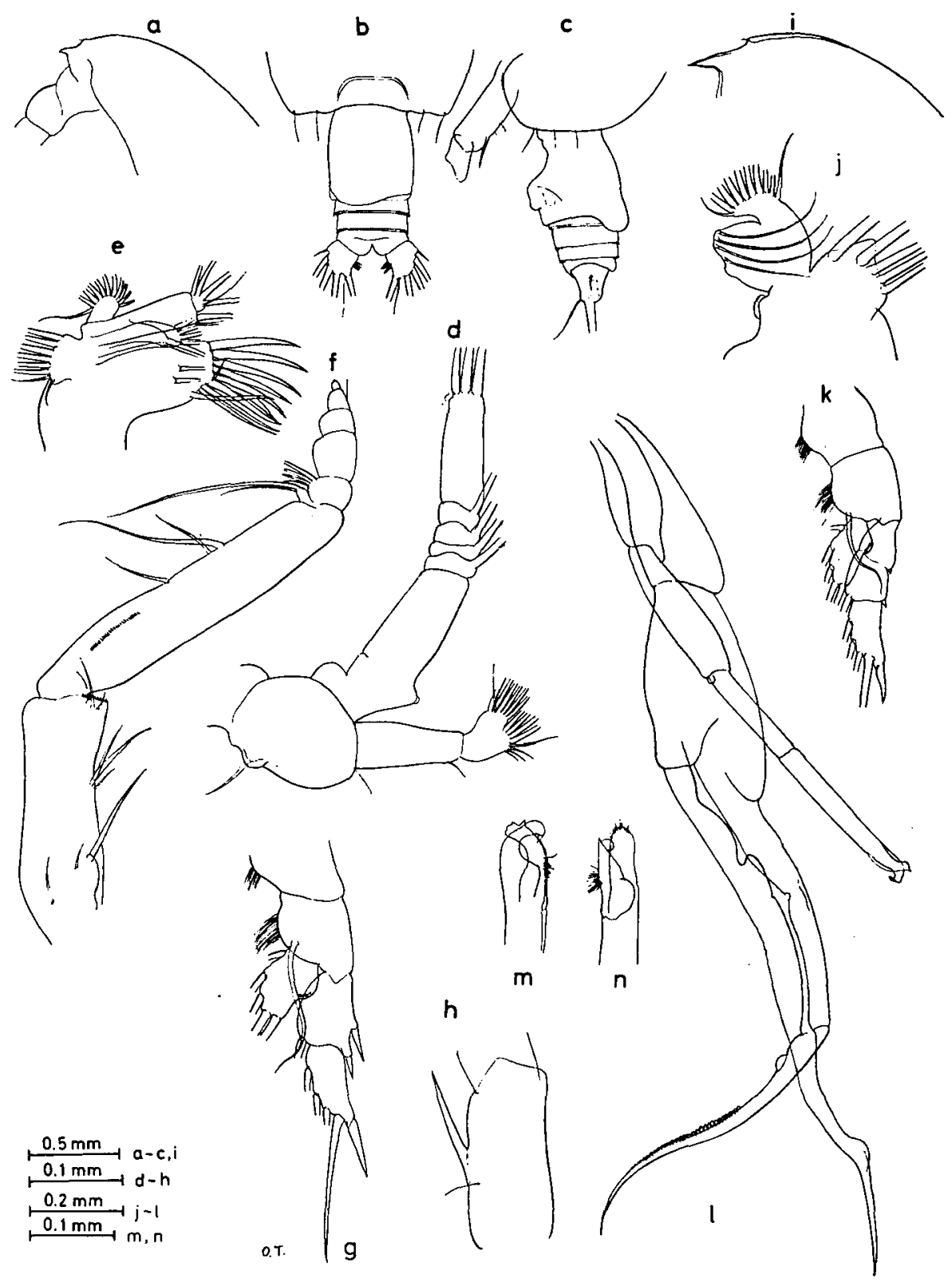

Fig. 1. Euchirella acuta, new species, female: $a$, head, lateral view; $b$, last thoracic segment and and abdomen, dorsal view; $c$, last thoracic segment and abdomen, lasteral view; $d$, 2nd antenna; $e$, lst maxilla; $f$, maxilliped; $g$, lst leg; $h$, 4th leg, 1st basal segment. male: $i$, head, lateral view; $j$, lst maxilla; $k$, lst leg; $l$, 5 th pair of legs; $m$, left 5 th leg, distal segment of exopod; $n$, another view of the same. 
measures about $4.8 \mathrm{~mm}$ in length: the segments are in the following proportional length :

\begin{tabular}{|c|c|c|c|c|c|c|c|c|c|c|c|c|}
\hline segment & 12 & 3 & 4 & 5 & 6 & 7 & $8-9$ & 10 & 11 & 12 & 13 & 14 \\
\hline & 6253 & 25 & 21 & 23 & 23 & 23 & 39 & 27 & 29 & 25 & 53 & 50 \\
\hline $\begin{array}{ll}16 & 17\end{array}$ & $18 \quad 19$ & 20 & 21 & 22 & 23 & $24-25$ & & & & & & \\
\hline $\begin{array}{ll}63 & 69\end{array}$ & 6063 & 56 & 46 & 46 & 37 & 42 & & & & & & \\
\hline
\end{tabular}

The 2nd antenna has an exopod which is 2.2 times the length of the endopod. The 1st and 2nd segments of the exopod are fused, and there is a conical papilla on the inner proximal margin of the fused segments. The distal segment of the endopod carries 7 setae on the outer lobe, and 8 setae on the inner lobe. In the mandible the cutting blade is provided with 7 teeth and an inner marginal seta. The 1st maxilla has the following numbers of setae on the various lobes: 8 setae on the outer lobe; 11 setae on the exopod; 5 setae on the endopod; 3 setae on the 2 nd basal segment; 2 setae on the 3rd inner lobe; 4 setae on the 2 nd inner lobe; 13 setae on the lst inner lobe. In the 2 nd maxilla the 1 st to 5 th lobes are each furnished with 3 setae; the endopod with 7 setae. In the maxilliped the 2 nd basal segment is 1.4 times the length of the lst one. The 1st basal segment is furnished with a row of remarkable teeth on the outer distal margin: the 2nd basal segment has a row of spinules on the proximal outer margin.

The 1st leg has a 2-jointed exopod and a 1-jointed endopod. In the 1st segment of the exopod there are 2 spines on the outer margin. The 2 nd leg has a 3 -jointed exopod and a 1 -jointed endopod; the terminal spine of the exopod has 20 teeth. In the 4 th leg the 1 st basal segment has a slender spine on the inner margin which exceeds the distal margin of the 1st basal segment.

Male, 3.85-3.89 $\mathrm{mm}$ (holotype, $3.89 \mathrm{~mm}$ ). The cephalothorax and abdomen are in the proportional lengths as 80 to 20 . The cephalothorax is 2.2 times as long as wide. The forehead resembles that of $E$. venusta but the rostrum is more robust.

The abdominal segments and furca are in the following proportional lengths:

$\begin{array}{lrrrrrc}\text { segment } & 1 & 2 & 3 & 4 & 5 & \text { furca } \\ & 29 & 26 & 16 & 13 & 3 & 13=100\end{array}$

The 2nd and 3rd segments are fringed with fine teeth on the lateral distal margin: the 4th segment is fringed with leaf-like processes only on the dorsal distal margin; the furcal rami are as long as wide.

The lst antennae extend to the end of the 1st abdominal segment. They are 20-jointed on the right and 21-jointed on the left, and measure $3.8 \mathrm{~mm}$ in length. The segments have the following proportional lengths: 


\begin{tabular}{|c|c|c|c|c|c|c|c|c|c|c|c|}
\hline segment & 1 & 2 & 3 & 4 & 5 & 6 & 7 & $8-9-10$ & 11 & $12-13$ & 14 \\
\hline right & 55 & 43 & 37 & 17 & 22 & 22 & 26 & 53 & 25 & 71 & 46 \\
\hline left & 53 & 50 & 36 & 20 & 22 & 20 & 22 & 58 & 28 & 70 & 44 \\
\hline $16 \quad 17$ & 18 & 19 & 20 & 21 & 22 & 23 & $24-25$ & & & & \\
\hline $64 \quad 70$ & 63 & 65 & 10 & & 60 & 51 & 48 & $=1000$ & & & \\
\hline $61 \quad 67$ & 61 & 64 & 58 & 50 & 58 & 50 & 50 & $=1000$ & & & \\
\hline
\end{tabular}

In the 2nd antenna the exopod and endopod are in the proportional lengths of 6 to 4 . The outer lobe of the endopod is provided with 6 setae; the inner lobe with 7 setae. The mandible has the usual structure with 8 setae on the distal margin of the 2nd segment of the endopod. In the 1st maxilla the exopod is furnished with 10 setae; the outer lobe has 2 large and 3 normal setae; the 1st inner lobe is represented by a process; the 2nd and 3rd inner lobes are absent; the endopod is furnished with 4 slender setae.

In the 1st leg the 1st and 2nd segments of the exopod are incompletely separated: the 1 st and 2nd segments have each a minute spine on the outer margin. In the 5 th pair of legs the 2nd basal segment of the left leg reaches the middle of the 2nd basal segment of the right leg. In the right leg the 1st and 2nd segments of the exopod are of equal lengths: the exopod is provided with 3 processes on the inner margin: the proximal one is large but low: the 2nd one is steep: the 3rd one is situated about the middle of the segment, and is very small. In males of the E. messinensis group there are usually 4 processes on the inner margin of the exopod. In the present specimen, however, the 4 th process is entirely absent. In the left leg a minute endopod is present on the distal margin of the 2nd basal segment. The exopod extends about to the proximal prominence of the exopod of the right leg. The 3rd segment of the exopod forms a claw which is characteristic in shape: it resembles that of E. venusta figured by Sewell (1947).

Remarks: The present female specimen resembles $E$. truncata. However, the genital segment is quite characteristic in shape. The male is similar to $E$. venusta, but is distinguished from it by the robust rostrum, the long basal segments of the left 5 th leg, the shape of the terminal claw of the exopod of the same leg, and the structure of the exopod of the right 5 th leg.

\section{Euchirella amoena GIESBRECHT, 1888}

Euchirella amoena Giesrrecht, 1892, p. 233, pl. 15, fig. 20; Esterly, 1905, p. 155, fig. 21 ; Mori, 1937, p. 42, pl. 18, figs. 1-9; Grice, 1962, p. 194, pl. 10, figs. 5-10; Vervoort, 1963, p. 135.

Euchirella brevis SARS, 1925, p. 71, pl. 21, figs. 1-7.

Euchirella bella (partim).- WiLson, 1950, p. 218.

Occurrence: U.S.N.M. No. 122507, 5 ad. ơ; U.S.N.M. No. 122508, 1 ad. o;; 


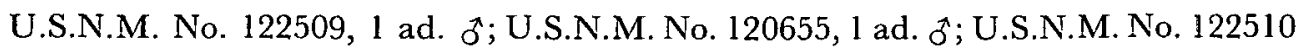
1 ad. $\delta$.

Remarks: The species is easily recognized by the following characteristics: a triangular rostrum, a strong spine on the mandibular palp, 4 to 6 triangular spines on the inner margin of the lst basal segment of the 4th leg, and 3 setae on the outer lobe and one seta on the inner lobe of the 2 nd antenna in the female. The male has a strong spine on the 1st segment of the exopod of the right 5th leg; the 2nd antenna has $6+6$ setae on the distal segment of the endopod.

The distribution and variation in length are listed in the following table:

\begin{tabular}{|c|c|c|c|c|c|}
\hline & \multirow[t]{2}{*}{ Locality } & \multirow[t]{2}{*}{ Depth } & \multicolumn{2}{|c|}{ Length (mm) } \\
\hline \multicolumn{2}{|l|}{ Author } & & & $q$ & o \\
\hline ESTERLY, & 1905 & San Diego region & - & - & 3.02 \\
\hline SARS, & 1925 & Atlantic & surface & 3.9 & - \\
\hline MORI, & 1937 & $\begin{array}{l}\text { Off Cape } \\
\text { Shionomisaki }\end{array}$ & surface & 3.5 & 3.3 \\
\hline GricE, & 1962 & $\begin{array}{c}\text { Equatorial } \\
\text { Pacific }\end{array}$ & $63-119 m$ & $3.61-3.80$ & $3.20-3.3$ \\
\hline VERVOOR? & 1963 & $\begin{array}{c}\text { Canary-Cape } \\
\text { Verde Is. }\end{array}$ & $0-\quad 4 \mathrm{~m}$ & $3.20-3.50$ & 3.30 \\
\hline $\begin{array}{r}\text { TANAKA a } \\
\text { (un }\end{array}$ & $\begin{array}{l}\text { d OMORI } \\
\text { ubl.) }\end{array}$ & Izu region & $0-1250 \mathrm{~m}$ & 4.00 & - \\
\hline Present reco & & Off Peru & surface & 4.00 & $.40-3$ \\
\hline
\end{tabular}

\section{Euchirella bella GIESBRECHT, 1888}

(Fig. 2, a-l)

Euchirella bella GIESBRECHT, 1892, p. 232, pl. 15, fig. 26; SEWELL, 1947, p. 71, fig. 13; Vervoort, 1949, p. 17, figs. 8a, 9c, 9g; Grice, 1962, p. 194, pl. 9, figs. 1-13.

Euchirella areata TANAKA, 1957, p. 186, fig. 50.

Euchirella venusla $(\hat{o})$.- TANAKA, 1957, p. 182, fig. 47, f, g.

Occurrence: U.S.N.M. No. 67073, 17 ad. $q, 5$ juv. $q$; U.S.N.M. No. 67074, 1 ad. + ; U.S.N.M. No. 67075, 12 ad. +5 juv. + ; U.S.N.M. No. 120653, 1 ad. $ð ;$ U.S.N.M. No. 67084, 6 ad. + , 1 juv. + ; U.S.N.M. No. 67085, 1 ad. $\delta$; U.S.N.M. No. 67122, 1 ad. o; U.S.N.M. No. 67123, 1 ad. $q$; U.S.N.M. No. 67124, 1 ad. $q, 3$ juv. ${ }^{\prime} 3$ juv. $ð$; U.S.N.M. No. 67125, 1 ad. $q$; U.S.N.M. No. 67134, 1 ad. $q$; U.S.N.M.

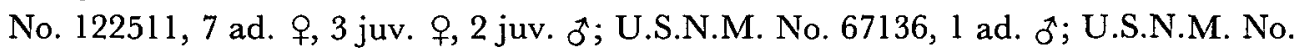

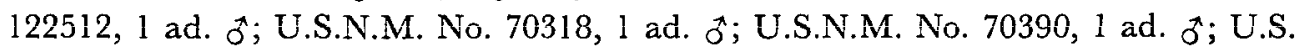
N.M. No. 73897, 1 ad. q; U.S.N.M. No. 80216, 1 ad. $q$.

Remarks: E. areata is a synonym of E. bella, as pointed out by VERvOoRT (1963). The identity of the male of $E$. bella described by Wilson (1950) is doubtful. His female specimen appears to be the female of $E$. pulchra. The present male and female specimens agree fairly well with those described by SewELL (1947). 
In the female the genital segment is asymmetrical; it is produced more on the right side when viewed dorsally: in lateral view the proximal half of the segment is concave, and is provided with a ridge on that area. The genital, $3 \mathrm{rd}$, and 4 th abdominal
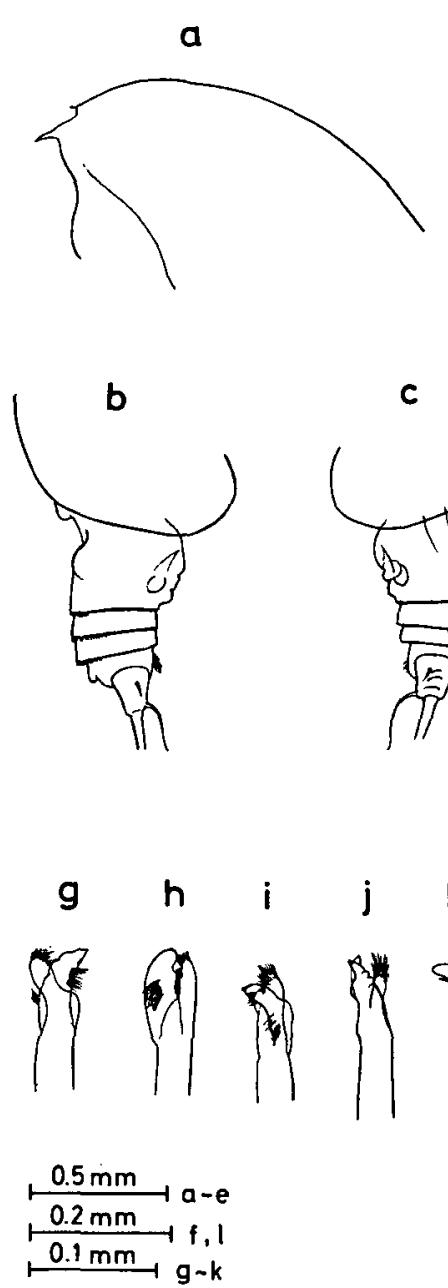
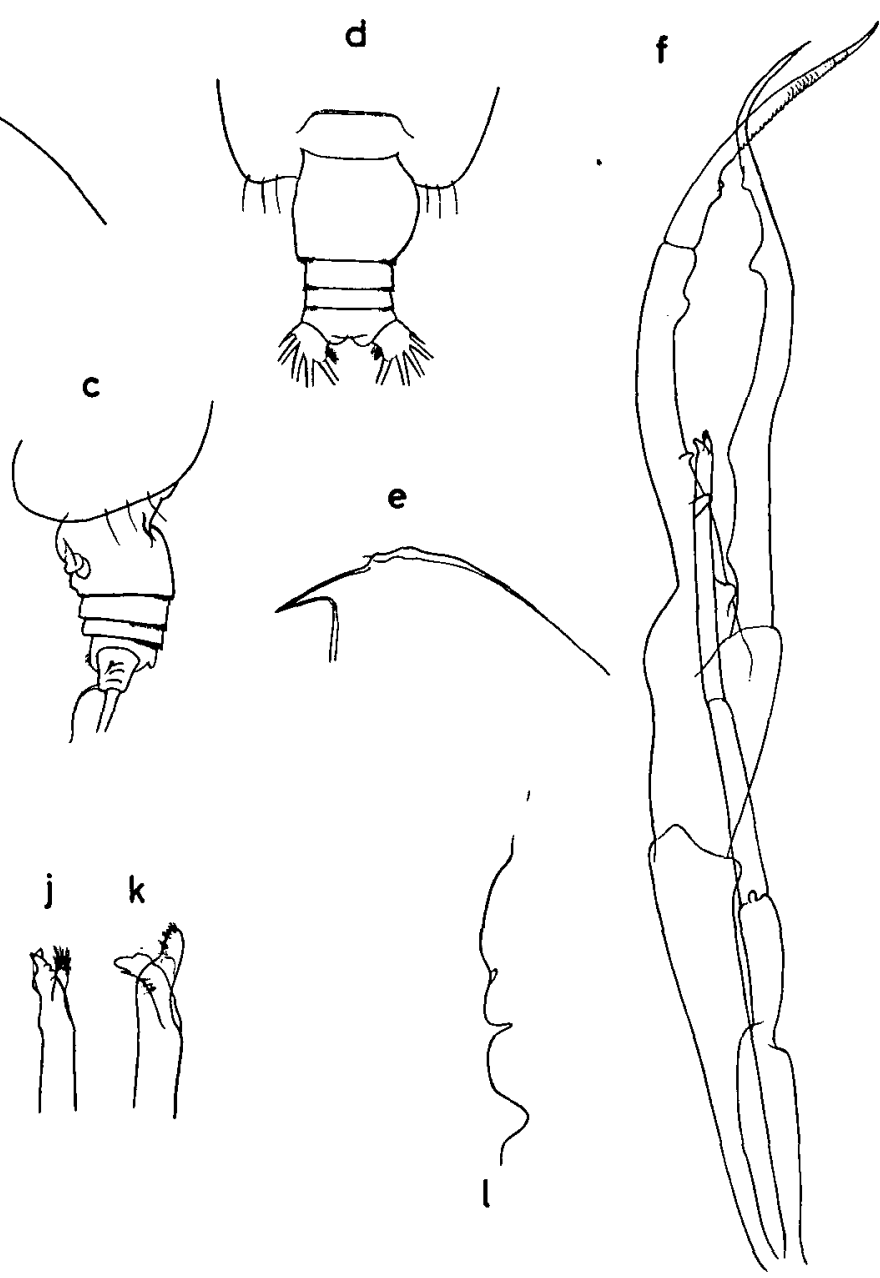

Fig. 2. Euchurella bella Giesbrecht, female: $a$, head, lateral view; $b$, last thoracic segment and abdomen, lateral view from right side; $c$, last thoracic segment and abdomen, lateral view from left side; $d$, last thoracic segment and abdomen, dorsal view. male: $e$, head, lateral view; $f$, 5th pair of legs; $g$, left 5 th leg, distal segment of exopod (Tansei Maru specimen, $3.50 \mathrm{~mm}$ ); $h$, the same (Albatross specimen, $3.30 \mathrm{~mm}$ ); $i$, the same (Albatross specimen, $3.40 \mathrm{~mm}$ ); $j$, the same (Albatross specimen, $3.33 \mathrm{~mm}$ ); $k$, the same (Tansei Maru specimen, $3.70 \mathrm{~mm}$ ); $l$, right 5 th leg, inner margin of exopod (Albatross specimen, $3.40 \mathrm{~mm}$ ).

segments are fringed with fine teeth on the distal margin. In the 2nd antenna the distal segment of the endopod has 4 setae on the outer lobe and 5 setae on the inner lobe, although GrICE (1962) states that there are 5 setae on each lobe. The number of 
spines on the lst basal segment of the 4th leg is variable: some specimens have 5 spines on the right leg and 4 spines on the left one, others have 4 and 3 respectively.

In the male the 2nd antenna has the endopod furnished with 6 setae both on the outer and inner lobes. The 5th pair of legs is like that figured by SEwELL (1947). He shows the distal segment of the exopod of the left leg with a small spine on the outer margin, but the spine is absent in some of the present specimens. The claw on the distal segment of the exopod of the left leg varies in shape according to the orientation of the 5th pair of legs. E. bella closely resembles $E$. venusta in the shape of the forehead and the structure of the 5th pair of legs, but it is distinguished from the latter by the more produced frontal margin of the head. According to SEwELL (1947), the species is confined to the Indo-Pacific region.

\begin{tabular}{|c|c|c|c|c|c|}
\hline \multirow[t]{2}{*}{ Author } & & \multirow[t]{2}{*}{ Locality } & \multirow[t]{2}{*}{ Depth } & \multicolumn{2}{|c|}{ Length $(\mathrm{mm})$} \\
\hline & & & & 우 & ot \\
\hline Sewell, & 1947 & Arabian Sea & $0-100 \mathrm{~m}$ & $3.68-3.86$ & 3.50 \\
\hline VERVOORT, & 1949 & Sawoe Sea & $0-60 \mathrm{~m}$ & - & 3.15 \\
\hline TANAKA, & 1957 & Sagami Bay & $0-1000 \mathrm{~m}$ & 3.75 & 3.70 \\
\hline Grice, & 1962 & $\begin{array}{l}\text { Equatorial } \\
\text { Pacific }\end{array}$ & $0-100 \mathrm{~m}$ & $3.80-4.18$ & $3.33-3.36$ \\
\hline \multicolumn{2}{|c|}{$\begin{array}{c}\text { TANAKA and OMORI } \\
\text { (unpubl.) }\end{array}$} & Izu region & $0-800 \mathrm{~m}$ & $3.70-3.90$ & 3.30 \\
\hline \multicolumn{2}{|l|}{ Present record } & Off Peru & $0-300 \mathrm{fms}$ & $3.80-4.85$ & $3.26-3.36$ \\
\hline
\end{tabular}

Euchirella bitumida WITH, 1915

(Fig. 3, a-g)

Euchirella bitumida WITH, 1915, p. 131, text-fig. 34, pl. 5, fig. 9, pl. 8, fig. 4; VERVOORT, 1949, p. 35, fig. 17; WiLson, 1950, p. 219, pl. 23, figs. 332-335; TANAKA, 1957, p. 189, fig. 52; Vervoort, 1963, p. 144; OWRE and Foyo, 1967, p. 46, figs. 254, 255, 257.

Euchirella galeata.-SEWELL, 1947, p. 74, fig. 14.

Occurrence: U.S.N.M. No. 70315, 1 juv. ơ; U.S.N.M. No. 122513, 1 ad. ㅇ․

Descriptive notes: Male. The specimens from the Izu region measure 4.90-5.10 $\mathrm{mm}$ in length; this is much smaller than those described by WILson (1950) which measured 5.90-6.10 $\mathrm{mm}$.

The cephalothorax and abdomen are in the proportional lengths as 80 to 20 . The forehead has a high crest which terminates in a rather pointed apex when viewed laterally.

The abdominal segments and furca have the following proportional lengths:

$\begin{array}{lrrrrrr}\text { segment } & 1 & 2 & 3 & 4 & 5 & \text { furca } \\ & 29 & 24 & 15 & 12 & 5 & 15=100\end{array}$

Segments 2-4 are each furnished with fine teeth on the distal margin. 
The 1st antenna extends beyond the end of the furca: it measures about $5.0 \mathrm{~mm}$ in length: the segments of the left antenna have the following proportional lengths:

\begin{tabular}{lrrrrrrrrrrrr} 
segment & 1 & 2 & 3 & 4 & 5 & 6 & 7 & $8-9-10$ & 11 & $12-13$ & 14 & 15 \\
\cline { 2 - 10 } & 52 & 51 & 32 & 20 & 22 & 22 & 22 & 61 & 28 & 71 & 47 & 66
\end{tabular}

$\begin{array}{cccccccccc}16 & 17 & 18 & 19 & 20 & 21 & 22 & 23 & 24-25 & \\ 62 & 68 & 62 & 63 & 55 & 43 & 49 & 41 & 63 & =1000\end{array}$

The 2nd antenna has a 7-jointed exopod which is 1.4 times the length of the endopod. The distal segment of the endopod is furnished with 6 long setae on the outer lobe, and 5 long and one short setae on the inner lobe. The mandible is strongly built; the endopod has 8 setae on the distal segment. In the lst maxilla the outer lobe has 6 setae; the endopod has 10 setae; the 1st to 3rd inner lobes are much reduced. The 2nd maxilla is reduced. In the maxilliped the 1st basal segment is a little less than the length of the 2 nd basal segment; these segments are slender.

In the 1st leg the exopod is 2-jointed; the 1st segment has 2 minute spines on the outer margin. In the 5 th pair of legs the distal margin of the 2 nd basal segment of the left leg reaches about the proximal one-third the length of the 2nd basal segment of the right leg. In the left leg the distal segment forms a claw which varies in shape according to the direction from which it is observed. In the right leg the lst segment of the exopod is furnished with 4 prominences on the inner margin, of which the 3rd is very small.

Remarks: E. bitumida, both male and female, resembles $E$. galeata so closely that SEWELl (1947) stated that they are identical and E. bitumida is the Atalanitc form of $E$. galeata. He said that the slight differences in the character of the genital segment, on which the distinction is based, should only be regarded as significant at the level of varieties rather than species. However, the species differ in the first place in the shape of the forehead; in E. bitumida the head has a high triangular crest, whereas it is helmet-shaped and rounded at the apex in $E$. galeata. The genital segment is asymmetrical in both species. But, it is more produced on the right side than on the left in E. bitumida, while, it is more produced on the left side in $E$. galeata. In the 2nd antenna the endopod is distinctly longer in E. bitumida than in E. galeata.

The distribution and variation in length appear from the following table:

\begin{tabular}{|c|c|c|c|c|c|}
\hline \multirow[t]{2}{*}{ Author } & & \multirow[t]{2}{*}{ Locality } & \multirow[t]{2}{*}{ Depth } & \multicolumn{2}{|c|}{ Length ( $\mathrm{mm}$ ) } \\
\hline & & & & q & $\hat{\sigma}$ \\
\hline WrTH, & 1915 & North Atlantic & $250-400 \mathrm{~m}$ & $6.6-7.1$ & - \\
\hline Sewell, & 1947 & Arabian Sea & $0-400 \mathrm{~m}$ & 6.10 & - \\
\hline VERVOORT, & 1949 & Flores Sea & $0-2000 \mathrm{~m}$ & 6.15 & - \\
\hline WILSON, & 1950 & Off Philippines & $0-290 \mathrm{fms}$. & $6.1-6.7$ & $5.9-6.1$ \\
\hline
\end{tabular}




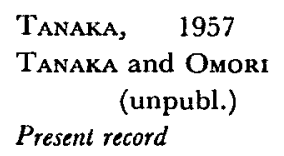

$\begin{array}{lccc}\text { Sagami Bay } & 0-1000 \mathrm{~m} & 6.07 & - \\ \text { Izu region } & 0-680 \mathrm{~m} & 5.87-6.58 & 4.90-5.10 \\ & & & \\ \text { China Sea } & 0-500 \mathrm{fms} . & 6.30 & -\end{array}$
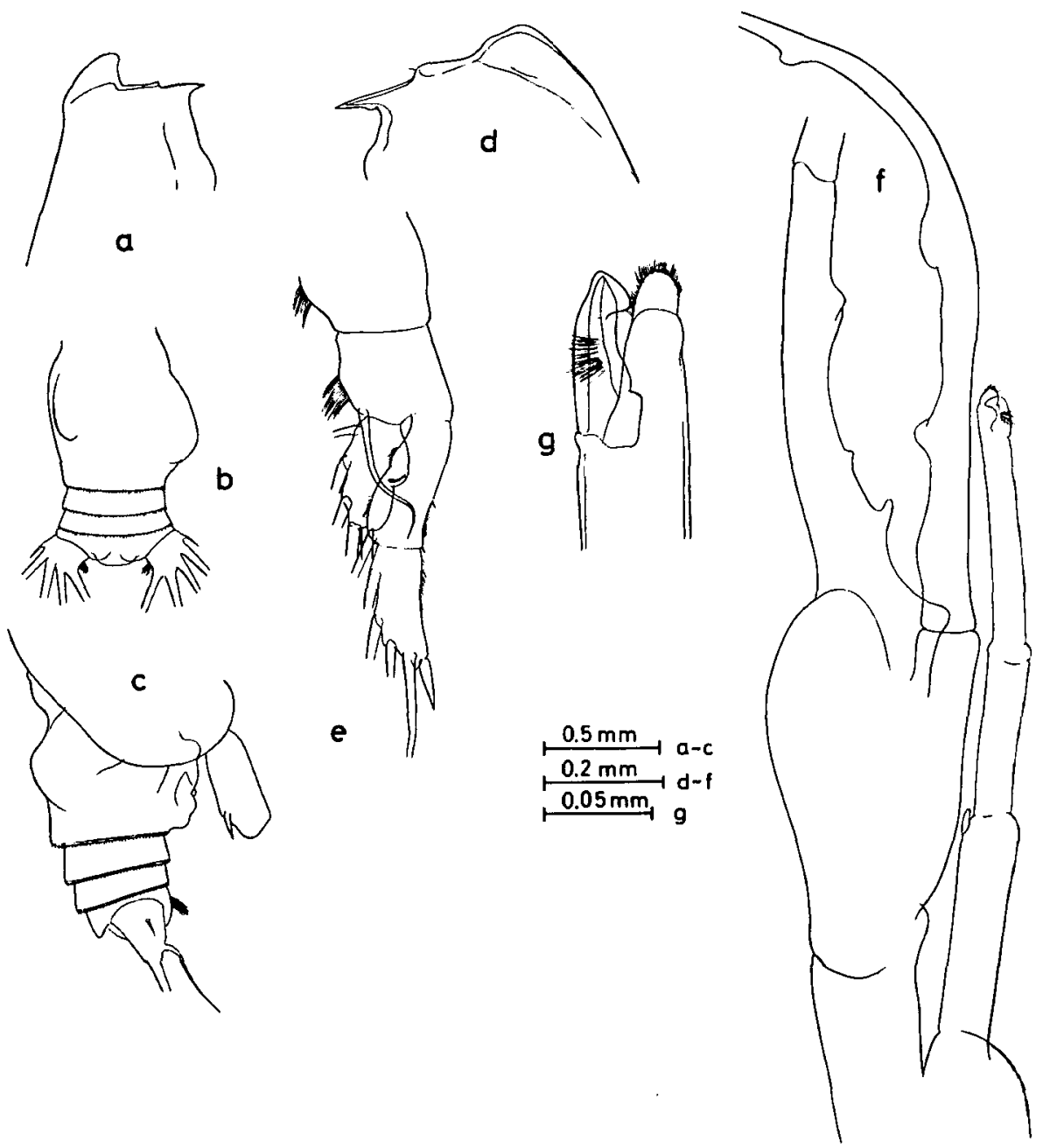

Fig. 3. Euchirella bitumida Wrth, female: $a$, head, lateral view; $b$, last thoracic segment and abdomen, dorsal view; $c$, last thoracic segment and abdomen, lateral view. male (Tanse $i$ Maru specimen): $d$, head, lateral view; $e$, 1 st leg; $f$, 5th pair of legs; $g$, left 5 th leg, distal segment of exopod.

\section{Euchirella curticauda GIESBRECHT, 1888}

Euchirella curticauda Gresbrecht, 1892, p. 233, pl. 15, figs. 3, 13, 25, pl. 36, figs. 19, 20; EsterLy, 1906, p. 59, pl. 9, fig. 6, pl. 10, fig. 27, pl. 12, fig. 62, pl. 13, fig. 67; SARs, 1925, p. 72, pl. 21, figs. 8-14; Sewell, 1929, p. 109, fig. 41 ; Davis, 1949, p. 30, pl. 3, figs. 38-41; Wilson, 1950, p. 221, pl. 23, fig. 
336; Brodsky, 1950, p. 176, fig. 92; TANAKA, 1957, p. 187, fig. 51 ; Grice, 1962, p. 196, pl. 10, figs. 11-14; Vervoort, 1963, p. 148; OWRe and Foyo, 1967, p. 46, figs. 258-261.

Occurrence: U.S.N.M. No. 70313, 1 ad. .q, 1 juv. $q$; U.S.N.M. No. 122514, 1 ad. + ; U.S.N.M. No. 122515, 1 juv. o.

Remarks: The species is easily recognized by the forehead which is provided with a high crest and a short rostrum. The lateral margin of the last thoracic segment is rounded and has a small additional process on the distal margin. The number of spines on the inner margin of the 1st basal segment of the 4 th leg varies from 8 to 11 .

The distribution and size variation of the species are as follows:

\begin{tabular}{|c|c|c|c|c|c|}
\hline \multirow{2}{*}{\multicolumn{2}{|c|}{ Author }} & \multirow[t]{2}{*}{ Locality } & \multirow[t]{2}{*}{ Depth } & \multicolumn{2}{|c|}{ Length $(\mathrm{mm})$} \\
\hline & & & & $q$ & $\delta$ \\
\hline Giesbrecht, & 1892 & Pacific & $0-1500 \mathrm{~m}$ & 3.5 & - \\
\hline A. ScotT, & 1909 & Malay Archipelago & $0-700 \mathrm{~m}$ & - & - \\
\hline ESTERLY, & 1906 & San Diego region & $0-400 \mathrm{fms}$ & 3.6 & - \\
\hline SARs, & 1925 & Atlantic & $0-1500 \mathrm{~m}$ & 4.40 & - \\
\hline Davis, & 1949 & Off Cape Flattery & $0-1100 \mathrm{~m}$ & $2.5-4.8$ & $3.0-4.3$ \\
\hline BRODSKY, & 1950 & $\begin{array}{c}\text { Far eastern seas } \\
\text { of the USSR }\end{array}$ & $0-\quad 50 \mathrm{~m}$ & 4.4 & 4.3 \\
\hline TANAKA, & 1957 & Izu region & $0-1000 \mathrm{~m}$ & 3.50 & 3.14 \\
\hline GRICE, & 1962 & Equatorial Pacific & $0-150 \mathrm{~m}$ & $3.52-3.62$ & - \\
\hline $\begin{array}{r}\text { TANAKA and } \\
\text { (unp }\end{array}$ & $\begin{array}{l}\text { OMORI } \\
\text { ubl.) }\end{array}$ & Izu region & $0-1100 \mathrm{~m}$ & 3.94 & - \\
\hline Present record & & $\begin{array}{l}\text { Off California } \\
\text { and off Philippines }\end{array}$ & $0-100 \mathrm{fms}$ & $3.30-3.77$ & - \\
\hline
\end{tabular}

\section{Euchirella galeata GIESBRECHT, 1888}

(Figure 4, a-k)

Euchirella galeata Giesbrecht, 1892, p. 233, pl. 15, fig. 18, pl. 36, figs. 22, 26; Esterly, 1905, p. 155, fig. 22; Sewell, 1929, p. 110, fig. 41; Vervoort, 1949, p. 32, fig. 16; Wilson, 1950, p. 221. pl. 8, figs. 85-88, pl. 9, figs. 89-91, pl. 23, fig. 337.

Occurrence: U.S.N.M. No. 67078, 1 ad. ㅇ, 2 juv. 우 U.S.N.M. No. 67128, 1 ad. $\phi$; U.S.N.M. No. 122518, 3 ad.,+ 7 ad. $\delta, 1$ juv. $q, 4$ juv. $\delta$; U.S.N.M. No. 73900,56 ad. $q, 4$ juv. $q$; U.S.N.M. No. 73901, 42 ad. $q, 1$ juv. $q, 5$ juv. $\delta$; U.S.N.M. No. 74392, 1 ad. +; U.S.N.M. No. 122519, 1 ad. ‡.

Descriptive notes: Male, $4.70-5.25 \mathrm{~mm}$. The cephalothorax and abdomen are in the proportional lengths as 80 to 20 . The forehead is helmet-shaped in lateral view and is rounded at the apex.

The abdominal segments and furca are in the following proportional lengths: 

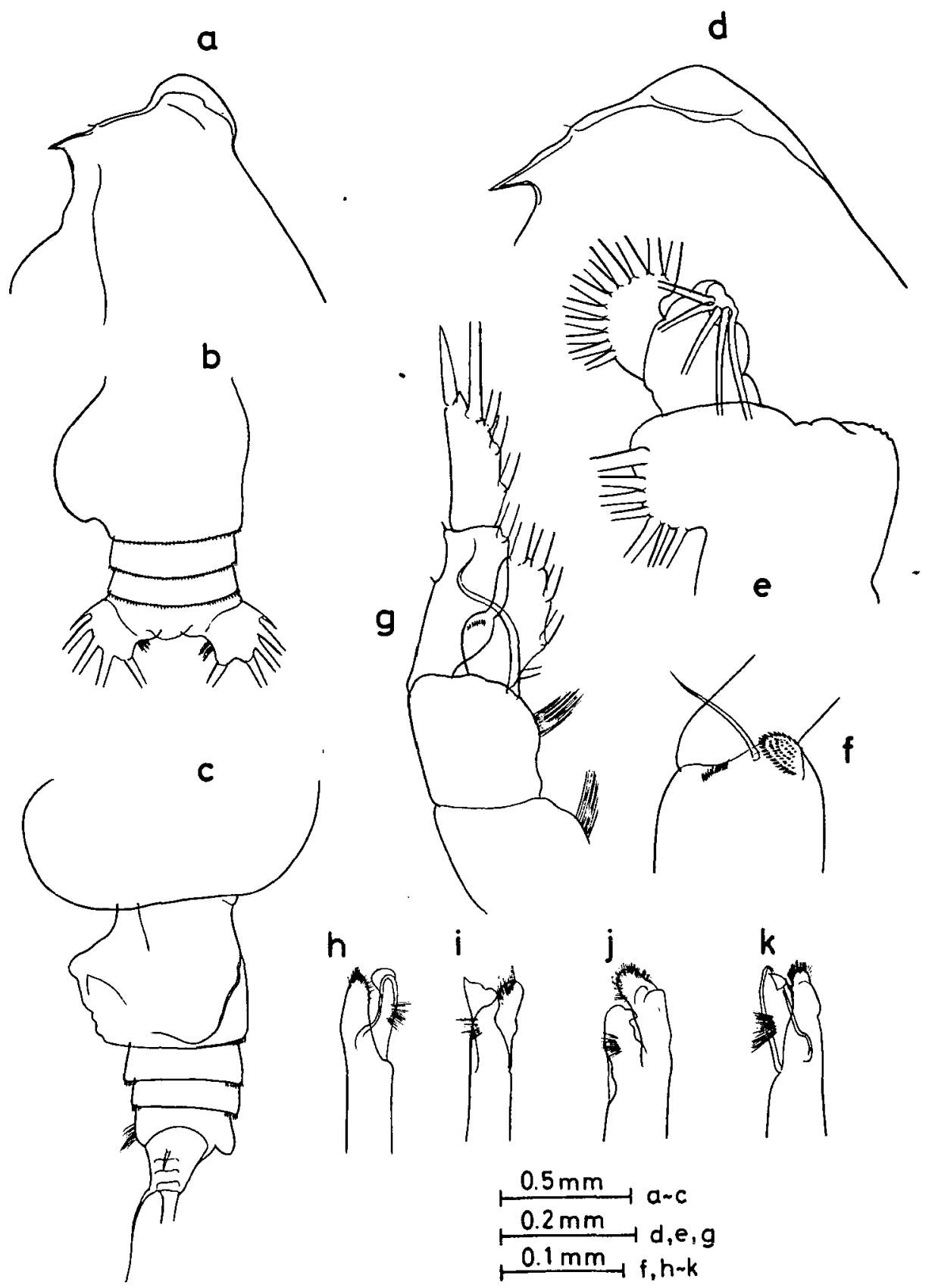

Fig. 4. Euchirella galeala Giessrecht, female: $a$, head, lateral view; $b$, adbomen, dorsal view; $c$, last thoracic segment and abdomen, lateral view. male: $d$, head, lateral view; $e, 1$ st maxilla; $f$, maxilliped, distal part of 1 st basal segment; $g$, lst leg; $h$, left 5 th leg, distal segment of exopod (Albatross specimen, $4.70 \mathrm{~mm}$ ); $i$, another view of the same; $j$, the same (Albatross specimen, $5.00 \mathrm{~mm}$ ); $k$, the same (Tansei Maru specimen, $5.13 \mathrm{~mm}$ ). 
\begin{tabular}{lrrrrrr} 
segment & 1 & 2 & 3 & 4 & 5 & furca \\
\cline { 2 - 6 } & 24 & 29 & 14 & 14 & 5 & 14
\end{tabular}$=100$

The 2nd to 4th abdominal segments are fringed with fine teeth on the distal margin.

The lst antenna has the segments in the following proportional lengths:

\begin{tabular}{|c|c|c|c|c|c|c|c|c|c|c|c|c|c|}
\hline & nent & & & 2 & 3 & 4 & 5 & 6 & 7 & $8-9-10$ & 11 & $12-13$ & 14 \\
\hline & ght & & 9 & 53 & 35 & 25 & 25 & 22 & 22 & 62 & 29 & 71 & 45 \\
\hline & & & & 49 & 30 & 26 & 24 & 22 & 22 & 61 & 30 & 71 & 5 \\
\hline 15 & 16 & 17 & 18 & 19 & 20 & 21 & 22 & 22 & & $4-25$ & & & \\
\hline 66 & 64 & 70 & 59 & 66 & & 96 & 47 & 3 & & 45 & 000 & & \\
\hline 68 & 66 & 71 & 59 & 66 & 53 & 43 & 49 & 3 & & 47 & 000 & & \\
\hline
\end{tabular}

The proportional lengths of the segment come near to those of E. bitumida except that of segment 24-25: in E. bitumida the last segment is 1.5 times the length of the 23rd, whereas, it is 1.2 times in E. galeata.

The mouth parts and 1st to 4th swimming legs are like those of E. bitumida. The 5th pair of legs is just like that of E. bitumida.

Remarks: The present species and $E$. bitumida are very closely related. However, they are easily separated by the shape of the forehead in both sexes, and by the shape of the genital segment in the female.

\begin{tabular}{|c|c|c|c|c|c|}
\hline \multirow{2}{*}{\multicolumn{2}{|c|}{ Author }} & \multirow[t]{2}{*}{ Locality } & \multirow[t]{2}{*}{ Depth } & \multicolumn{2}{|c|}{ Length (mm) } \\
\hline & & & & 우 & $\delta$ \\
\hline ESTERLy, & 1905 & San Diego region & - & 6.5 & - \\
\hline SEWELl, & 1929 & Bay of Bengal & $0-200 \mathrm{fms}$ & - & - \\
\hline VERVOORT, & 1949 & Equatorial Pacific & $0-60 \mathrm{~m}$ & $5.20-5.90$ & - \\
\hline WiLson, & 1950 & Off Peru & $0-300 \mathrm{fms}$ & 5.86 & 5.33 \\
\hline \multicolumn{2}{|c|}{$\begin{array}{c}\text { TANAKA and OMORI } \\
\text { (unpubl.) }\end{array}$} & Izu region & $0-360 \mathrm{~m}$ & 6.00 & - \\
\hline \multicolumn{2}{|l|}{ Present record } & Pacific & - & $5.50-6.70$ & $4.70-5.25$ \\
\hline
\end{tabular}

\section{Euchirella grandicornis WILSON}

(Figure 5, a-i)

Euchirella grandicornis WiLson, 1950, p. 223, pl. 9, figs. 98-100, pl. 10, figs. 101-105. [ 9 only; $\delta=E$. maxima WolFENDEN].

Occurrence: U.S.N.M. No. 123606, 16 ad. ㅇ, 7 juv. + , 2 juv. $\delta^{\star} ; \quad$ U.S.N.M. No. 67129,45 ad. ㅇ, 12 juv. 우 2 juv. $\delta$; U.S.M.N. No. 67130,6 ad. 우, 4 juv. 우; U.S.N.M. No. 67131, 1 ad. $q$; U.S.N.M. No. 70734, 1 juv. + , 10 juv. đ․

Descriptive notes: Female, 5.97-6.80 mm. The specimen dissected (lectotype, 
U.S.N.M. No. 67131) measured $6.18 \mathrm{~mm}$ in length.

The cephalothorax and abdomen are in the proportional lengths as 82 to 18 . The cephalothorax is 2.5 times as long as wide. The frontal margin of the head
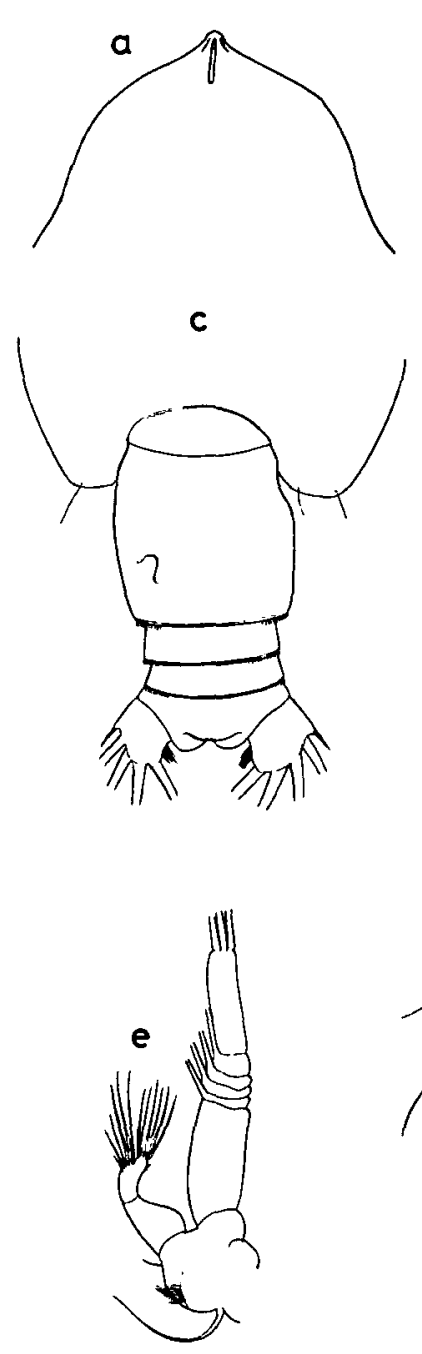
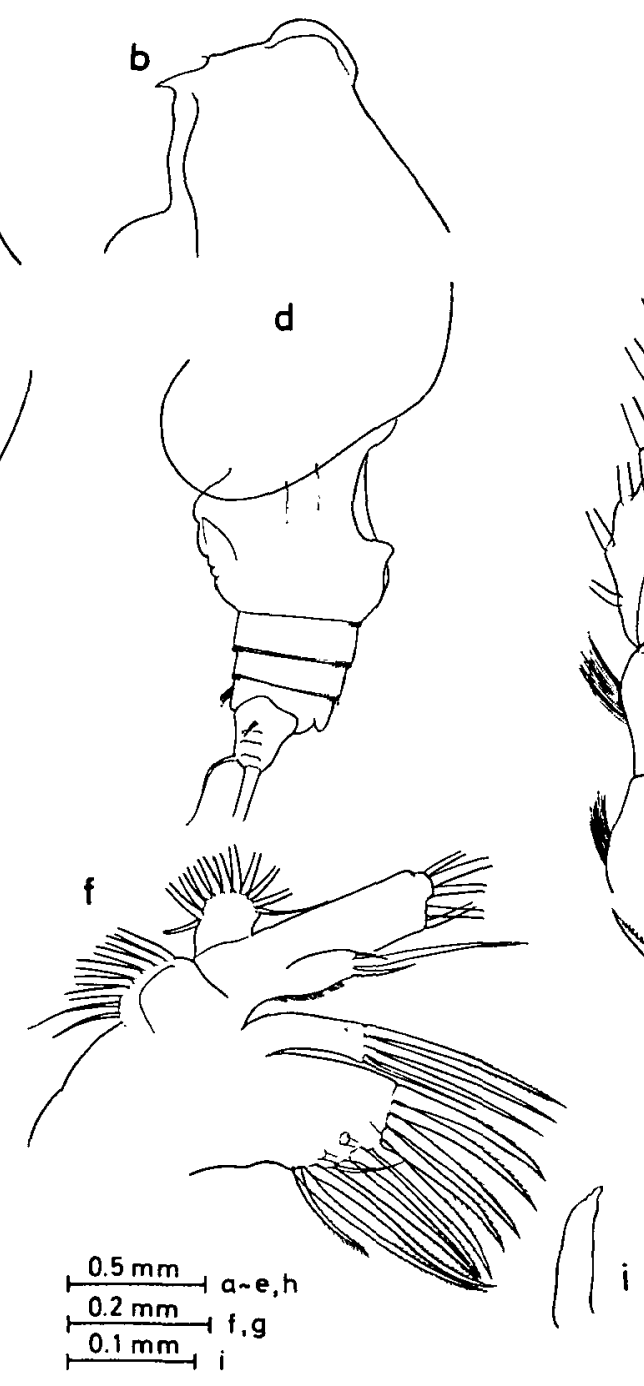

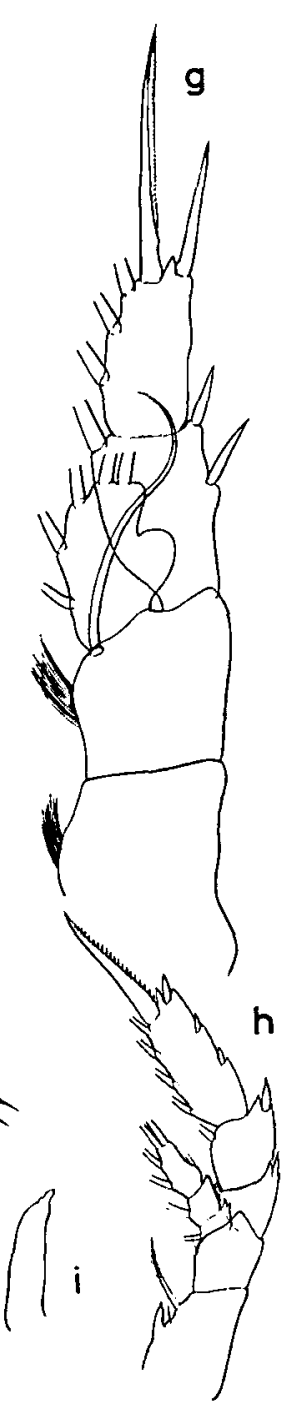

Fig. 5. Euchirella grandicornis WiLson, female: $a$, head, dorsal view; $b$, head, lateral view, $c$, last thoracic segment and abdomen, dorsal view; $d$, last thoracic segment, lateral view; $e$, 2nd antenna; $f$, Ist maxilla; $g$, lst leg; $h$, 4th leg; $i$, 4th leg, lateral spine of 1 st basal segment.

has a low rounded crest when viewed from the side. The rostrum is small but sharply pointed. The lateral margin of the last thoracic segment is broadly rounded. The abdomen is 4-jointed; the segments and the furca are in the following 
proportional lengths :

\begin{tabular}{lrrrrr} 
segment & $1-2$ & 3 & 4 & 5 & furca \\
\cline { 2 - 5 } & 56 & 14 & 10 & 6 & 14
\end{tabular}$=100$

The genital segment is about as long as wide: it is asymmetrical, having a remarkable process on the dorsal surface near the left margin. The distal margins of the genital, $3 \mathrm{rd}$, and 4 th segments are fringed with fine teeth.

The 1st antenna is 23-jointed, and extends to the distal margin of the furca: the various segments are in the following proportional lengths:

\begin{tabular}{|c|c|c|c|c|c|c|c|c|c|c|c|c|c|c|c|}
\hline gr & ient & 1 & 2 & 3 & 4 & 5 & 6 & 7 & $8-9$ & 10 & 11 & 12 & 13 & 14 & 15 \\
\hline & ght & 67 & 62 & 30 & 23 & 26 & 25 & 27 & 40 & 28 & 33 & 25 & 46 & 46 & 67 \\
\hline & & 67 & 65 & 22 & 22 & 23 & 25 & 25 & 42 & 27 & 28 & 25 & 45 & 42 & \\
\hline 16 & 17 & 18 & 19 & 20 & 21 & 22 & 23 & 24 & 25 & & & & & & \\
\hline 59 & 68 & 58 & 62 & 52 & 42 & 42 & 31 & 31 & 10 & & 000 & & & & \\
\hline 62 & 70 & 62 & 67 & 55 & 44 & 42 & 33 & 33 & 10 & & 000 & & & & \\
\hline
\end{tabular}

The 2nd antenna has the exopod 2.6 times the length of the endopod. The distal segment of the endopod is furnished with 6 setae on the outer lobe, and 6 setae on the inner lobe. The mandibular palp is robust: the exopod has 6 setae: the endopod has 7 long and 2 short setae on the distal segment. The cutting edge is very simple. The 1st maxilla has the following numbers of setae on the various lobes: 8 setae on the outer lobe; 11 setae on the exopod; 3 setae on the endopod; 3 setae on the 2 nd basal segment; 3 setae on the 3 rd inner lobe; 4 setae on the 2 nd inner lobe; 13 setae on the lst inner lobe. In the 2nd maxilla the endopod carries 7 setae; the lst to 5 th lobes have each 3 setae. The maxilliped is, according to WILson (1950), characteristic, but it is of the usual structure found in other members of the genus Euchirella.

In the 1 st leg the exopod is composed of 2 segments. The 1st segment is furnished with 2 spines on the outer margin. The 2 nd leg has a 3 -jointed exopod and a 1 jointed endopod. The 3rd and 4th legs have each a 3 -jointed exopod and endopod. In the 4th leg the lst basal segment has only single spine on the inner margin, although WiLson (1950) described it as having 9 long spines. The spine is not pointed at the apex but narrowly rounded. The terminal spine of the exopod of the 4th leg is furnished with coarse teeth, about 20 in number.

Remarks: The species is closely allied to $E$. galeata, differing from it in the shape of the genital segment. The male described by Wilson (1950) under the name $E$. grandicornis is the male of E. maxima. According to him, the proximal half of the lst antenna of the female is quite regularly and densely setose, and on the distal half the setae are irregularly scattered. However, it is of a normal structure like that found in other members of the genus. 


\section{Euchirella maxima WOLFENDEN, 1905}

Euchirella maxima, A. ScotT, 1909, p. 57, pl. 12, figs. 12-20; Wolfenden, 1911, p. 238, text-fig. 24, pl. 28, figs. 3-5; Sars, 1925, p. 75, pl. 22, figs. 1-7; Sewell, 1929, p. 112, figs. 42, 43; Sewell, 1947, p. 88, fig. 19; Wruson, 1950, p. 225, pl. 25, figs. 338, 339; GRICE, 1962, p. 196, pl. 10, fig. 15; Vervoort, 1963, p. 147; OWRe and Foyo, 1967, p. 47, figs. 262-266.

Euchirella simplex Esterly, 1911, p. 320, pl. 26, fig. 10, pl. 29, figs. 50, 62.

Occurrence: U.S.M.N. No. 122460, 1 ad. ఫ̋; U.S.N.M. No. 122523, 1 juv. ఫే; U.S.N.M. No. 1225241 ad. +2 juv. đ; U.S.N.M. No. 122525, 1 ad. + .

Remarks: The present specimens agree quite well with the description given by SEWELL (1947). The 5th pair of legs in the male resembles that of the genus Gaetanus. Some records of the distribution and size variation are summarized as follows:

\begin{tabular}{|c|c|c|c|c|c|}
\hline \multirow{2}{*}{\multicolumn{2}{|c|}{ Author }} & \multirow[t]{2}{*}{ Locality } & \multirow[t]{2}{*}{ Depth } & \multicolumn{2}{|c|}{ Length (mm) } \\
\hline & & & & 우 & $\sigma^{*}$ \\
\hline A. Scotт, & 1909 & Malay Archipelago & $0-1000 \mathrm{~m}$ & 7.20 & - \\
\hline WOLFENDEN, & 1911 & South Atlantic & $0-300 \mathrm{~m}$ & $7.50-8.70$ & - \\
\hline EsterLy, & 1911 & San Diego region & $0-315 \mathrm{fms}$ & 6.36 & - \\
\hline WITH, & 1915 & North Atlantic & $0-600 \mathrm{~m}$ & $7.8-8.5$ & 6.7 \\
\hline SEWELL, & 1929 & Bay of Bengal & $0-200 \mathrm{fms}$ & $6.1-6.5$ & - \\
\hline SEWELL, & 1947 & Arabian Sea & $0-1500 \mathrm{~m}$ & 7.25 & 7.02 \\
\hline WiLson, & 1950 & Off Philippines & $0-100 \mathrm{fms}$ & - & 7.60 \\
\hline VERVOORT, & 1963 & Gulf of Guinea & $100-600 \mathrm{~m}$ & 7.50 & $6.10-7.35$ \\
\hline OWRE and F & $\begin{array}{l}\text { OYo, } \\
1967\end{array}$ & Florida Current & $287-684 \mathrm{~m}$ & $7.0-7.5$ & - \\
\hline $\begin{array}{r}\text { TANAKA and } \\
\text { (un }\end{array}$ & $\begin{array}{l}\text { OMORI } \\
\text { publ.) }\end{array}$ & Izu region & $0-360 \mathrm{~m}$ & $7.00-7.50$ & - \\
\hline Present record & & Pacific & - & $7.35-7.60$ & 6.90 \\
\hline
\end{tabular}

\section{Euchirella messinensis indica, new rank}

(Figure 6, f-m)

Euchirella messinensis.-A. Scotr, 1909, p. 56; WILson, 1950, p. 225; TANAKA, 1957, p. 180, fig. 46. Euchirella indica VERVOORT, 1949, p. 23, figs. 8b, 9b, 11, 12a, b.

Occurrence: U.S.N.M. No. 67081, 4 ad. + ; U.S.N.M. No. 67132, 2 ad. $q$; U.S.N.M. No. 122521, 2 ad. क; U.S.N.M. No. 70389, 1 ad. $ð$; U.S.N.M. No. 73904, 3 ad. ㅇ, 2 ad. శ̊; U.S.N.M. No. 122522, 2 ad. 우 U.S.N.M. No. 120656, 1 ad. s.

Descriptive notes: Female, 4.40-4.90 $\mathrm{mm}$. The cephalothorax and abdomen are in the proportional lengths as 82 to 18 . The forehead is rounded, and there is no trace of a crest. The abdominal segments and furca are in the following proportional lengths: 


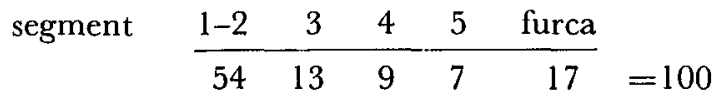

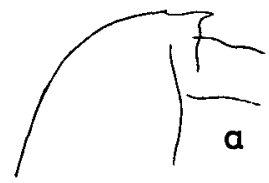

$b$
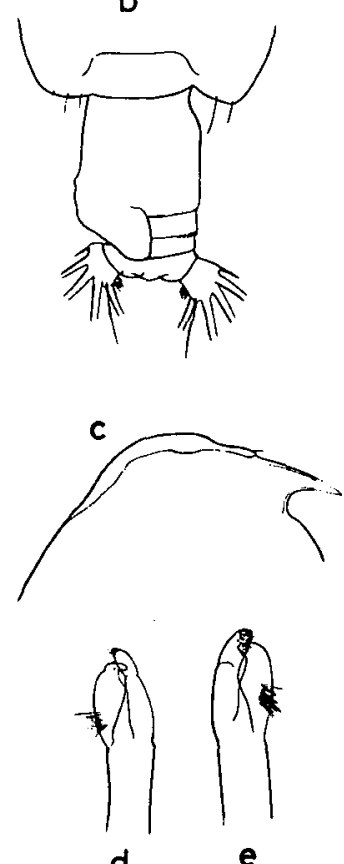

d

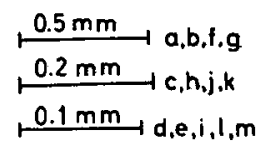

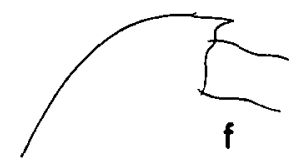

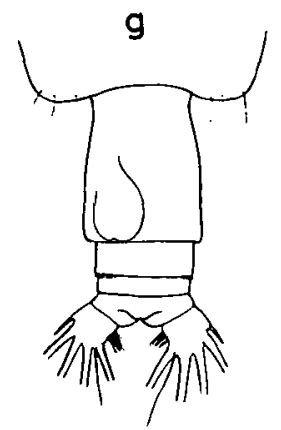

g

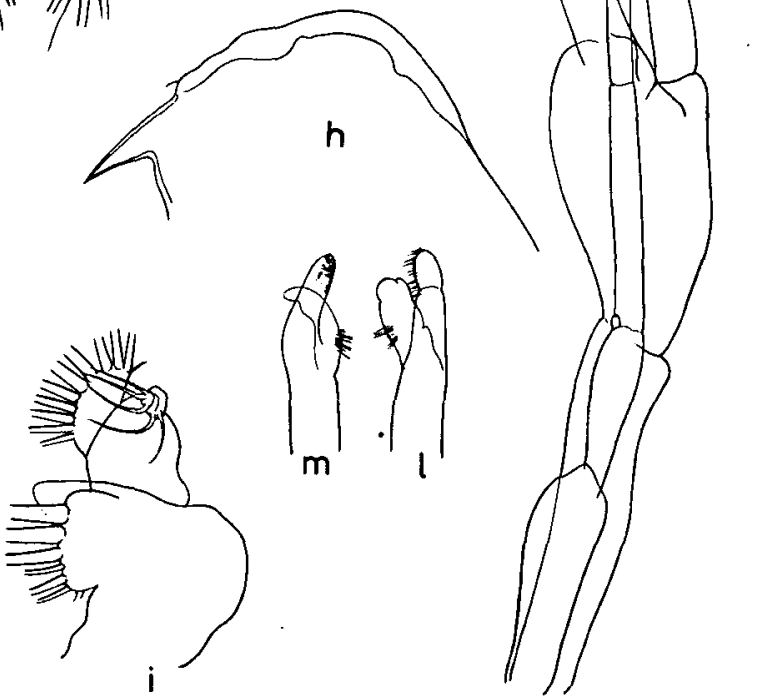

Fig. 6. Euchirella messinensis (Claus), female: $a$, head, lateral view (Atlantide specimen, $5.50 \mathrm{~mm}$ ); $b$, last thoracic segment and abodomen, dorsal view (WHOI, No. 273 specimen, $4.40 \mathrm{~mm}$ ). male: $c$, head. lateral view (WHOI, No. 66 specimen, $4.39 \mathrm{~mm}$ ); $d$, left 5th leg, distal segment of exopod; $e$, another view of the same.

Euchirella messinensis indica, female: $f$, head, lateral view (Tansei Maru specimen, $4.90 \mathrm{~mm}$ ); $g$, last thoracic segment and abdomen, dorsal view. male: $h$, head, lateral view (Albatross specimen, $4.60 \mathrm{~mm}$ ); $i$, 1st maxilla; $j$, 1st leg; $k$, 5th pair of legs; $l$, left 5 th leg, distal segment of exopod; $m$, the same (Tansei Maru specimen, $4.40 \mathrm{~mm}$ ).

The genital segment is a little longer than wide. In dorsal view the segment is nearly symmetrical in outline and carries a sac-like protuberance near the left distal margin. The protuberance scarcely reaches the distal margin of the segment. 
The development of the protuberance differs in various specimens. The 3rd segment is striated with fine teeth on the distal margin. The furcal rami are about as long as wide.

The 1st antenna extends to the distal margin of the 2nd abdominal segment. The segments are in the following proportional lengths:

\begin{tabular}{lcccccccccccccc} 
segment & & 1 & 2 & 3 & 4 & 5 & 6 & 7 & $8-9$ & 10 & 11 & 12 & 13 \\
\cline { 2 - 10 } & & 70 & 61 & 29 & 23 & 23 & 21 & 23 & 38 & 25 & 28 & 27 & 44 \\
14 & 15 & 16 & 17 & 18 & 19 & 20 & 21 & 22 & 23 & $24-25$ & & & \\
\hline 44 & 51 & 64 & 68 & 61 & 70 & 55 & 46 & 44 & 38 & 47 & $=1000$
\end{tabular}

In the 2nd antenna the exopod is 3.2 times the length of the endopod. The distal segment of the endopod has 5 setae on the outer lobe and 4 setae on the inner lobe; these setae are plumose. The mandible has a long inner marginal seta on the cutting blade. The 1st maxilla has the following numbers of setae on the various lobes: 8 setae on the outer lobe; 11 setae on the exopod; 4 setae on the endopod; 3 setae on the 2nd basal segment; 2 setae and a small process on the 3 rd inner lobe; 4 setae on the 2nd inner lobe; 13 setae on the 1st inner lobe. In the 2nd maxilla lobes 1-5 each have 3 setae; the endopod has 6 setae. The maxilliped has the following numbers of setae on the various lobes: $2+2+3$ setae on the lst basal segment; $3+2$ setae on the 2 nd basal segment; the 1 st to 5 th segments of the endopod have 4 , $3,3,3+1$, and 4 setae respectively.

The 1 st leg has structure quite similar to that of $E$. messinensis. In the 4 th leg the 1st basal segment has 2 unequal spines. In one of the specimens dissected the right leg has 3 , and the left one has 2 spines.

Male, 3.91-4.80 mm. "The cephalothorax and abdomen are in the proportional lengths as 76 to 24 . The forehead has a low but distinct crest. The rostrum is depressed and directed downwards. The abdominal segments and furca are in the following proportional lengths:

$\begin{array}{lrrrrrrr}\text { segment } & 1 & 2 & 3 & 4 & 5 & \text { furca } & \\ & 25 & 23 & 17 & 18 & 2 & 15 & =100\end{array}$

The left 1st antenna has the segments in the following proportional lengths:

\begin{tabular}{rrrrrrrrrrrrrrrrr}
\multicolumn{2}{c}{ segment } & & 1 & 2 & 3 & 4 & 5 & 6 & 7 & $8-9$ & 10 & 11 & 12 & 13 & 14 & 15 \\
& & 76 & 41 & 20 & 20 & 22 & 20 & 24 & 42 & 20 & 29 & 29 & 37 & 49 & 61 \\
16 & 17 & 18 & 19 & 20 & 21 & 22 & 23 & $24-25$ & & & & & & & \\
64 & 71 & 61 & 71 & 56 & 46 & 46 & 41 & 54 & $=1000$ & & & & & &
\end{tabular}

In the 2nd antenna the exopod is 1.4 times the length of the endopod. The 
distal segment of the endopod has 7 setae on the inner lobe, of which 2 are slender; the outer lobe has 6 setae. The mandible is of the usual structure; the endopod is furnished with 8 setae on the distal segment. The lst maxilla is reduced; the outer lobe has 6 long and 2 minute setae; the exopod has 10 long and one very short setae; the endopod has 5 setae; the 1 st to 3 rd inner lobes are completely reduced. The maxilliped is reduced; there is a single seta on the distal margin of the lst basal segment.

The 1st leg has a 2-jointed exopod and a 1-jointed endopod: there are no marginal spines on the outer margin of the 1 st segment of the exopod. The 5 th pair of legs agrees well with that of $E$. messinensis. In the left leg the basal segments extend as far as the distal margin of the lst basal segment of the right leg; the exopod extends a little beyond the proximal process on the endopod of the right leg: the lst segment of the exopod is shorter than the 2nd segment: the 3rd segment is inserted on the lateral side of the 2 nd one, forming the usual claw. In the right leg the exopod has, besides a blunt process near the base, 3 prominences, of which the proximal one is the largest; the 2nd segment of the exopod bears about 30 teeth along the inner magin.

Remarks: In the present study, the specimens, both female and male, obtained in the Pacific by the R/V Albatross, Carnegie, Snellius (Sta. 268) and Tansei Maru were all dissected and examined. They were carefully compared with the specimens of E. messinensis collected in the Atlantic (U.S.N.M. Nos. 69447 and 79512, WHOI Nos. 66 and 273, and Atlantide Sta. 139) (Fig. 6, a-e). All the Pacific specimens were identical with $E$. indica VERVOORT (1949), and except for the shape of the sac-like protuberance on the genital segment of the female there was no structual difference between $E$. messinensis and $E$. indica. We think these two are the same species, and $E$. indica is the Pacific subspecies of $E$. messinensis. As already noted by TANAKA (1957), E. messinensis indica is one of the most common species in the deep water of the Izu region. According to Vervoort (1949), all the Siboga specimens reported from the Malay Archpelago region by A. Scotr (1909) belongs to E. indica. Except for the record of Esterly (1905), there is no occurrence of the typical E. messinensis in the Pacific. In the Indian Ocean Grice and Hulsemann (1967) did not find $E$. indica but only E. messinensis. SEWELL (1929) and Vervoort (1949) recorded the occurrence of the male of $E$. messinensis from the Indian seas. The distribution and the variation in length are shown in the following table:

\begin{tabular}{|c|c|c|c|c|}
\hline \multirow[t]{2}{*}{ Author } & \multirow[t]{2}{*}{ Locality } & \multirow[t]{2}{*}{ Depth } & \multicolumn{2}{|c|}{ Length $(\mathrm{mm})$} \\
\hline & & & $q$ & o \\
\hline A. Sсотт, 1909 & Malay Archipelago & $0-750 \mathrm{~m}$ & - & - \\
\hline VERVOORT, 1949 & Malay Archipelago & $0-1500 \mathrm{~m}$ & $4.25-5.05$ & 3.4 \\
\hline TANAKA, 1957 & Izu region & $0-1000 \mathrm{~m}$ & 5.26 & 4.62 \\
\hline $\begin{array}{c}\text { TANAKA and OMori } \\
\text { (unpubl.) }\end{array}$ & Izu region & $0-360 \mathrm{~m}$ & $4.55-5.30$ & $4.15-4.70$ \\
\hline Present record & Pacific & - & $4.40-4.90$ & $3.91-4.80$ \\
\hline
\end{tabular}




\section{Euchirella orientalis SEWELL, 1929}

(Figure 7, a-i)

Euchirella orientalis SEwell, 1929, p. 115, fig. 44; 1947, p. 76, fig. 15.

Euchirella formosa VERvOORT, 1949, p. 29, figs. 14, 15; 1963, p. 134.

Euchirella trigrada TANAKA, 1957, p. 184, fig. 49.

Occurrence: U.S.N.M. No. 122516, 1 ad. o; U.S.N.M. No. 120660, 16 ad. ð; U.S.N.M. No. 122517, 1 ad. ㅇ; U.S.N.M. No. 120654, 1 ad. $q$.

Descriptive notes: Female, $5.25 \mathrm{~mm}$. The specimens examined were collected in the Izu region: they measure $5.55-5.70 \mathrm{~mm}$ in length.

The cephalothorax and abdomen are in the proportional lengths as 80 to 20 . The forehead is rounded, and there is no trace of a crest when viewed from the side.

The abdominal segments and furca have the following proportional lengths:

\begin{tabular}{lrrrrr} 
segment & $\frac{1-2}{-2}$ & 3 & 4 & 5 & furca \\
\hline 60 & 7 & 11 & 5 & 17
\end{tabular}$=100$

The genital segment has tubercles on the left side, which vary in number from one to three. The lateral profile of the genital swelling agrees in shape fairly well with that figured by SEwell (1947). The 3rd abdominal segment is fringed with fine teeth on the distal margin.

The lst antenna reaches the distal margin of the genital segment. In the 2nd antenna the endopod is short, about one-fourth the length of the exopod. The distal segment of the endopod is furnished with 5 setae on the outer lobe, and 4 setae on the inner lobe. The 1st maxilla has the following numbers of setae on the various lobes: 8 setae on the outer lobe; 11 setae on the exopod; 4 setae on the endopod; 3 setae on the 2 nd basal segments; 3 setae on the 3 rd inner lobe; 4 setae on the 2 nd inner lobe; 13 setae on the 1 st inner lobe. The maxilliped agrees well with that described by Sewell (1947).

In the 4th leg the 1st basal segment is provided with 2 unequal spines on the inner margin; the inner spine is longer than the outer one reaching the articulation of the 2 basal segments.

Male, 4.75-5.20 mm. The cephalothorax and abdomen are in the proportional lengths of 80 to 20 . The forehead has a low crest which resembles closely that of E. messinensis, but in the present species there is a small glittering lens-like prominence on the anterior margin at about the middle.

The abdominal segments and furca are in the following proportional lengths:

$\begin{array}{lllllll}\text { segment } & 1 & 2 & 3 & 4 & 5 & \text { furca }\end{array}$

$\begin{array}{lllllll}27 & 26 & 14 & 17 & 6 & 10=100\end{array}$ 
The 2nd and 3rd segments are striated with fine teeth on the distal margin.

The 1 st antennae extend to the end of the 2 nd abdominal segment; the segments have the following proportional lengths:
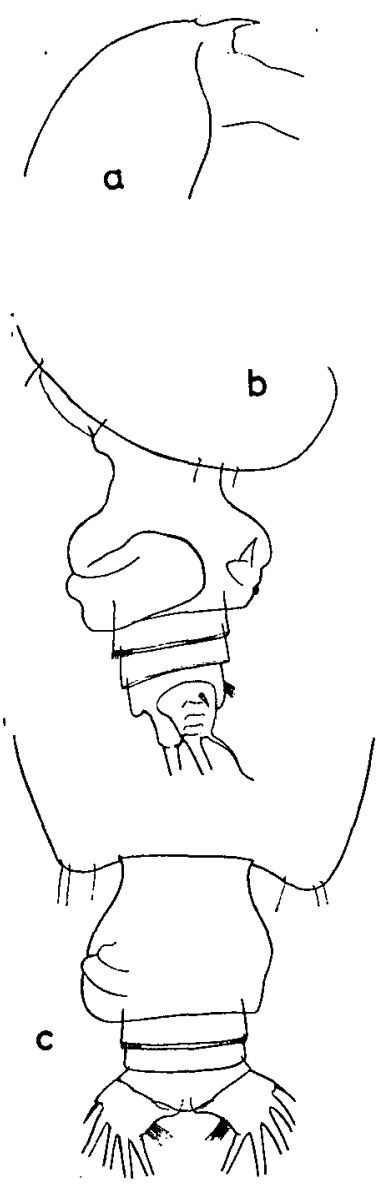

$0.5 \mathrm{~mm}$
$0.2 \mathrm{~mm}$
$0.1 \mathrm{~mm}$
$0, f, f, g$
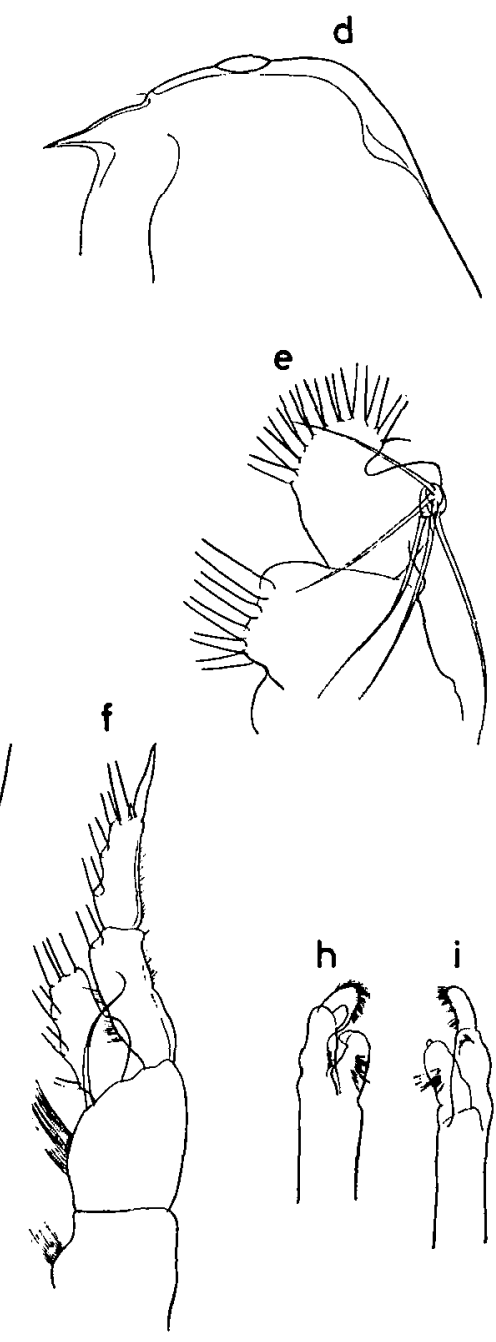

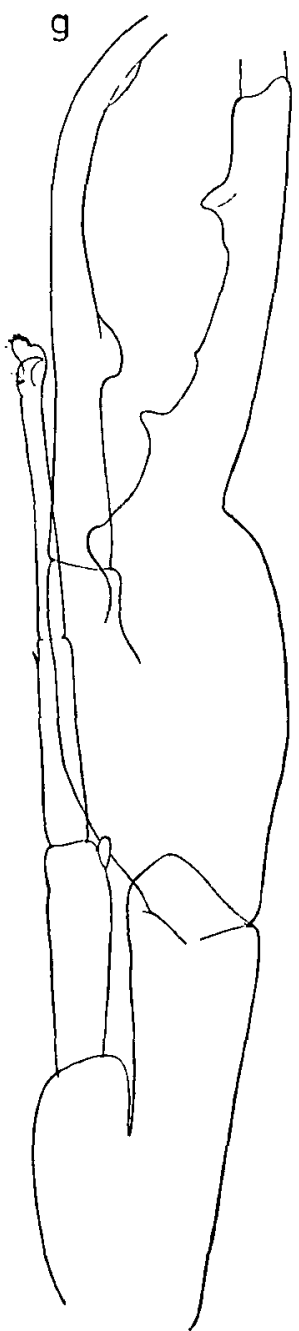

Fig. 7. Euchirella orientalis SeweLL, female: $a$, head, lateral view; $b$, last thoracic segment and adbomen, lateral view; $c$, last thoracic segment and abdomen, dorsal view. male: $d$, head, lateral view; $e$, 1st maxilla; $f, 1 \mathrm{st}$ leg; $g, 5$ th pair of legs; $h$, left 5 th leg, distal segment of exopod; $i$, the same (Tansei Maru specimen, $5.20 \mathrm{~mm}$ ). 


$\begin{array}{crrrrrrrrrrrrr}\text { segment } & 1 & 2 & 3 & 4 & 5 & 6 & 7 & 8-9-10 & 11 & 12-13 & 14 & 15 \\ \text { right } & 60 & 42 & 19 & 21 & 21 & 23 & 23 & 67 & 32 & 77 & 47 & 70 \\ \text { left } & 60 & 41 & 18 & 20 & 20 & 23 & 25 & 67 & 32 & 76 & 48 & 69 \\ 16 & 17 & 18 & 19 & 20 & 21 & 22 & 23 & 24-25 & & & & & \\ 65 & 72 & 63 & 65 & 98 & 49 & 42 & 44 & =1000 & & & & \\ 67 & 72 & 62 & 65 & 55 & 44 & 48 & 44 & 44 & =1000 & & & & \end{array}$

In the 2nd antenna the exopod is 1.5 times the length of the endopod. The distal segment of the endopod has 6 long setae on the outer lobe, and 5 long and one small setae on the inner lobe. In the 1st maxilla the 1st to 3rd inner lobes are much reduced. The outer lobe has 6 , the exopod has 10 setae; the endopod including the 2nd basal segment is furnished with 5 setae.

The 1st leg has a 2-jointed exopod and a 1-jointed endopod. There is a minute spine on the outer distal margin of the 1st segment of the exopod. The 5th pair of legs agrees well with that described by Sewell (1947). In the left leg the 2nd basal segment reaches beyond the distal end of the 1st basal segment of the right leg; the 2nd segment of the exopod is a little more than the length of the lst; the 3rd segment of the exopod forms a claw with the distal part of the 2nd segment; the shape of the claw is as figured by Sewell (1947): the 1st segment of the exopod has a minute spine on the outer distal margin. In the right leg the 1st segment of the exopod is provided with 4 processes on the inner margin; the 1st process is large but blunt; the 2nd and 4th ones are steep; the 3rd is very small.

Remarks: On close examination of E. orientalis, E. formosa, and E. trigrada we were convinced that these three species are identical; among them $E$. orientalis has priority. Although SEwell's figure $(1929,1947)$ of $E$. orientalis, especially the genital segment, is not complete, we judged that $E$. orientalis differs from $E$. formosa or E. trigrada only in the armature of the genital segment in the female. In SEWELI's specimen the distal margin of the genital segment of $E$. orientalis is furnished with spinules, whereas they are absent in E. formosa and E. trigrada. However, according to Vervoort (1949), a similar variation in armature is found among the specimens of $E$. venusta taken from the Malay Archipelago. The tubercles on the female's genital segment appear to be variable in number, from zero to three in E. orientalis.

The distribution and size variation of the species are as follows:

\begin{tabular}{|c|c|c|c|c|}
\hline \multirow[t]{2}{*}{ Author } & \multirow[t]{2}{*}{ Locality } & \multirow{2}{*}{ Depth } & \multicolumn{2}{|c|}{ Length (mm) } \\
\hline & & & 우 & o \\
\hline SEWELl, & Bay of Bengal & $0-400 \mathrm{fms}$. & 4.8 & 3.7 \\
\hline Sewell, & Arabian Sea & $0-200 \mathrm{~m}$ & $4.33-4.40$ & 4.77 \\
\hline VERVOORT, 1949 & Malay Archipelago & $0-60 \mathrm{~m}$ & $5.10-5.20$ & - \\
\hline $\begin{array}{c}\text { TANAKA and OMORI } \\
\text { (unpubl.) }\end{array}$ & Izu region & $0-680 \mathrm{~m}$ & $5.10-5.90$ & $4.80-5.15$ \\
\hline Present record & Western Pacific & _- & 5.25 & $4.75-5.20$ \\
\hline
\end{tabular}




\section{Euchirella pulchra (LuBBOCK, 1856)}

(Figure 8, a-f)

Euchirella pulchra, GiesBrecht, 1892, p. 233, pl. 15, figs. 22, 23, pl. 36, figs. 13, 27; EsterLy, 1905, p. 153, fig. 20; SARs, 1925, p. 69, pl. 20, figs. 5-7; SEwELL, 1947, p. 80, fig. 16; Davis, 1949, p. 31, pl. 3, figs. 42, 43, pl. 4, figs. 44-48; Vervoort, 1949, p. 20, fig. 9, d, h; Wilson, 1950, p. 225; TANaka, 1957, p. 178, fig. 45; Grice, 1962, p. 194, pl. 10, figs. 1-4; Vervoort, 1963, p. 145; OMORI, 1965, p. 64, figs. 19-21; OWRE and Foyo, 1967, p. 48, figs. 10, 269, 276.
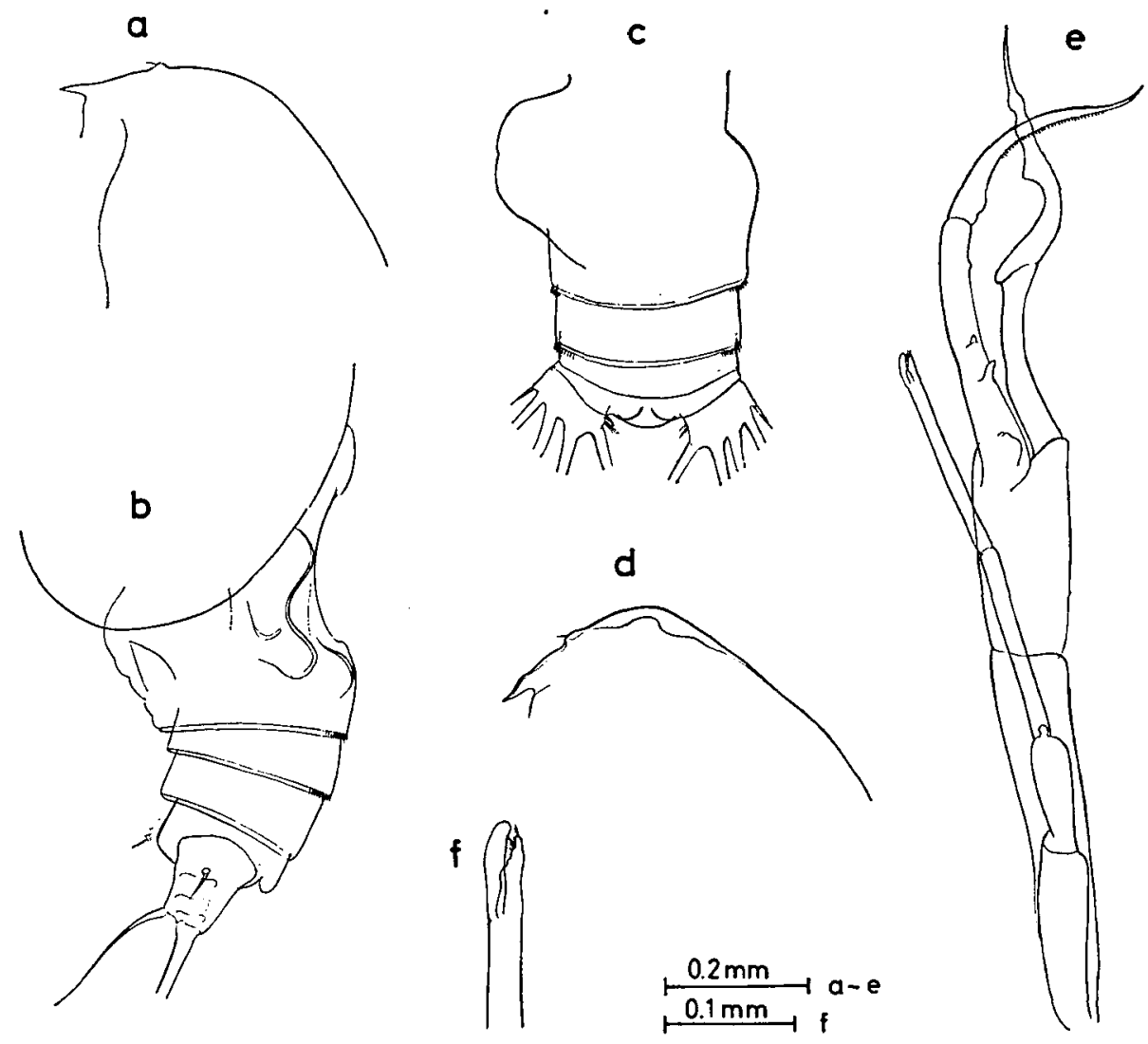

Fig. 8. Euchirella pulchra (Luввоск), female: $a$, head, lateral view; $b$, last thoracic segment and adbomen, lateral view; $c$, abdomen, dorsal view. male: $d$, head, lateral view; $e, 5$ th pair of legs; $f$, left 5 th leg, distal segment of exopod.

Occurrence: U.S.N.M. No. 67079, 2 ad. $q ;$ U.S.N.M. No. 67080, 2 ad. juv. + ; U.S.N.M. No. 73645, 1 ad. + ; U.S.N.M. No. 120658, 4 ad. $q, 3$ ad. $\delta$; U.S.M.N. No. 73905, 8 ad. ?.

Remarks: The female of $E$. pulchra is easily recognized by the round forehead and the round swelling on the left lateral margin of the genital segment. The 
distal segment of the endopod of the 2nd antenna carries 6 setae on the outer lobe, and 6 setae on the inner lobe. In the male the basal segments of the left leg of the 5th pair of legs are short, only reaching the middle of the 1st basal segment of the right leg.

\begin{tabular}{|c|c|c|c|c|c|}
\hline \multicolumn{2}{|l|}{ Author } & \multirow{2}{*}{ Locality } & \multirow{2}{*}{ Depth } & \multicolumn{2}{|c|}{ Length (mm) } \\
\hline & & & & q & a \\
\hline GIESBRECHT, & 1892 & Atlantic & - & 4.4 & - \\
\hline SEWELL, & 1947 & Arabian Sea & $0-200 \mathrm{~m}$ & 3.37 & 4.15 \\
\hline Davis, & 1949 & $\begin{array}{l}\text { Northeastern } \\
\text { Pacific }\end{array}$ & $0-100 \mathrm{~m}$ & $3.4-4.4$ & $3.0-3.8$ \\
\hline VERVOORT, & 1949 & $\begin{array}{l}\text { Malay } \\
\text { Archipelago }\end{array}$ & $160-250 \mathrm{~m}$ & $2.90-3.55$ & - \\
\hline TANAKa, & 1957 & Izu region & $0-1000 \mathrm{~m}$ & 3.47 & 3.06 \\
\hline GRICE, & 1962 & Equatorial Pacific & $0-169 \mathrm{~m}$ & 3.42 & - \\
\hline VERVOORT, & 1963 & Gulf of Guinea & $0-10 \mathrm{~m}$ & $3.13-3.70$ & - \\
\hline $\begin{array}{r}\text { TANAKA and } \\
\text { (ung }\end{array}$ & $\begin{array}{l}\text { OMORI } \\
\text { uti.) }\end{array}$ & Izu region & $0-800 \mathrm{~m}$ & $3.10-3.60$ & 3.14 \\
\hline Present record & & Western Pacific & - & $2.88-3.50$ & $3.09-3.15$ \\
\hline
\end{tabular}

\section{Euchirella rostrata (CLAUS, 1866)}

Euchirella rostrata, GiesBRECHT, 1892, p. 232, pl. 2, fig. 11, pl. 15, figs. 6, 27, 28, pl. 36, figs. 16, 17, 23; Esterly, 1905, p. 152, fig. 19; EsterLy, 1911, p. 321, pl. 29, fig. 52, pl. 30, fig. 60, pl. 32, fig. 116; Sars, 1925, p. 69, pl. 20, figs. 8-15; Davis, 1949, p. 30, pl. 3, figs. 33-37; Vervoort, 1957, p. 63; TANAKA, 1957, p. 177, fig. 44.

Occurrence: U.S.N.M. No. 122526, 1 ad. क; U.S.N.M. No. 122527, 1 juv. ᄋ; U.S.N.M. No. 80217,7 ad. + .

Remarks: This common species has been reported from various parts of the Pacific, Atlantic, and Indian Oceans. The species can be distinguished easily from other members of the genus by the structure of the genital segment in the female and the 5 th leg in the male. Some records of the distribution and size variation are shown in the following table:

\begin{tabular}{|c|c|c|c|c|c|}
\hline \multirow{2}{*}{\multicolumn{2}{|c|}{ Author }} & \multirow[t]{2}{*}{ Locality } & \multirow[t]{2}{*}{ Depth } & \multicolumn{2}{|c|}{ Length $(\mathrm{mm})$} \\
\hline & & & & $q$ & $\sigma^{*}$ \\
\hline Giesbrecht, & 1892 & Mediterranean Sea & - & $2.95-3.10$ & - \\
\hline ESTERLY, 1905 & 1911 & San Diego region & $0-60 \mathrm{fms}$. & $2.97-3.10$ & 3.00 \\
\hline FARRAN, & 1929 & Off New Zealand & surface & $3.15-3.40$ & - \\
\hline DAvis, & 1949 & Northeastern Pacific & $0-500 \mathrm{~m}$ & $2.0-4 . \overline{0}$ & $2.5-3.0$ \\
\hline WILSON, & 1950 & Off Philippines & surface & - & - \\
\hline Tanaka, & 1957 & Izu region & surface & 3.58 & 3.01 \\
\hline $\begin{array}{r}\text { TANAKA and } \\
\text { (un }\end{array}$ & $\begin{array}{l}\text { Pmori } \\
\text { publ.) }\end{array}$ & Izu region & $0-520 \mathrm{~m}$ & $3.35-3.95$ & - \\
\hline Present record & & $\begin{array}{l}\text { Off Peru and } \\
\text { East of Maryland }\end{array}$ & surface & $2.85-3.90$ & - \\
\hline
\end{tabular}




\section{Euchirella truncata ESTERLY, 1911}

(Figure 9, a-g)

Euchirella truncata EsterLY, 1911, p. 322, pl. 26, fig. 5, pl. 28, fig. 35, pl. 29, fig. 63, pl. 30, fig. 71 , pl. 31, fig. 104; SEWELL, 1947, p. 82, fig. 17.

Euchirella propria Esterly, 1911, p. 321, pl. 27, figs. 14, 20, pl. 30, figs. 67, 83, pl. 31, fig. 85.

Euchirella gracilis WolfENDEN, 1911, p. 273, pl. 27, figs. 8-10.

Euchirella intermedia WITH, 1915, p. 124, text-fig. 32, pl. 4, fig. 4, pl. 8, fig. 3; VERvoorT, 1949, p. 28, fig. 13; Wilson, 1950, p. 225; Tanaka, 1957, p. 183, fig. 48.

Occurrence: U.S.N.M. No. 122528, 2 ad. \%; U.S.N.M. No. 122529, 2 ad. \&; U.S.N.M. No. 120657, 1 ad. §־.

Descriptive notes: Male, $4.92 \mathrm{~mm}$. The specimen used for the examination was collected from Izu region: it measured $5.10 \mathrm{~mm}$ in length.

The cephalothorax and abdomen are in the proportional lengths as 80 to 20 . The forehead is rounded, without any distinct crest. The rostrum is moderately long, and is directed downwards. The lateral margin of the thoracic segment is rounded.

The abdominal segments and furca are in the following proportional lengths:

\begin{tabular}{lcccccc} 
segment & 1 & 2 & 3 & 4 & 5 & furca \\
\hline 27 & 22 & 18 & 18 & 4 & 11
\end{tabular}$=100$

The 1st antenna extends to the end of the furca; the segments are in the following proportional lengths:

\begin{tabular}{|c|c|c|c|c|c|c|c|c|c|c|c|}
\hline segment & 1 & 2 & 3 & 4 & 5 & 6 & 7 & $8-9-10$ & 11 & $12-13$ & 14 \\
\hline right & 57 & 36 & 18 & 16 & 22 & 22 & 24 & 65 & 30 & 77 & 47 \\
\hline left & 57 & 42 & 17 & 19 & 21 & 23 & 23 & 63 & 29 & 77 & 48 \\
\hline $\begin{array}{ll}16 & 17\end{array}$ & 18 & 19 & 20 & 21 & 22 & 23 & 24-25 & & & & \\
\hline $61 \quad 69$ & 61 & 65 & 11 & & 61 & 45 & 47 & $=1000$ & & & \\
\hline $\begin{array}{ll}65 & 69\end{array}$ & 63 & 67 & 63 & 50 & 50 & 43 & 43 & $=1000$ & & & \\
\hline
\end{tabular}

In the 2nd antcnna the exopod is about 1.4 times the length of the endopod. The distal segment of the endopod carries 6 long setae on the outer lobe, and 5 long and 2 short setae on the inner lobe. In the 1st maxilla the outer lobe is furnished with 6 setae; the exopod with 11 setae; the endopod including the 2nd basal segment with 5 setae; the other lobes are much reduced.

The 1st leg is of the usual structure: the 1st and 2nd segments of the exopod are fused, and these combined segments bear 2 small marginal spines. In the 5 th pair of legs the 2 nd basal segment of the left leg reaches the middle of the 2 nd basal 
segment of the right leg. In the left leg the 1st segment of the exopod is a little more than the length of the 2 nd segment; there is a minute spine on the inner distal margin of the 1st segment of the exopod: the 3rd segment of the exopod makes the usual claw with the distal part of the 2nd segment; the shape of the claw agrees well with that
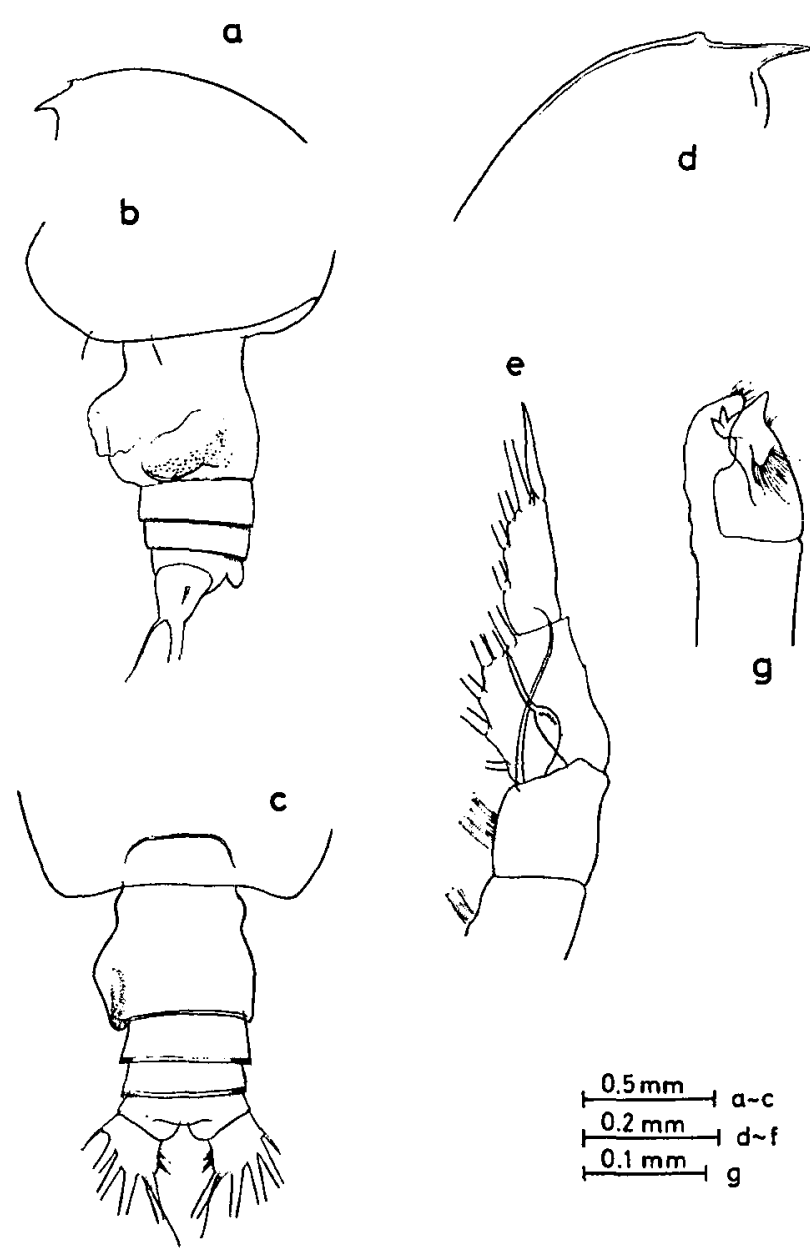
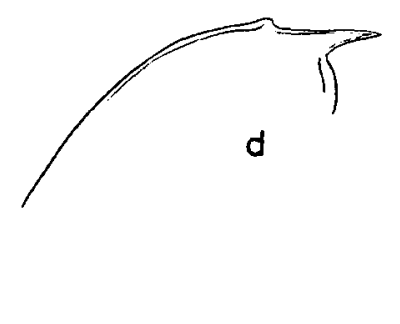

Fig. 9. Euchirella truncata Esterly, female: $a$, head, lateral view; $b$, last thoracic segment and abdomen, lateral view; $c$, last thoracic segment and abdomen, dorsal view. male: $d$, head, lateral view; $e, 1$ st leg; $f$, 5 th pair of legs; $g$, left 5 th leg, distal segment of exopod.

figured by EsTERLY (1911). In the right leg the lst segment of the exopod has 4 prominences on the inner margin of which the lst and 4th are remarkable; the endopod is furnished with 3 prominences of which the proximal one is very acute.

Remarks: The female is easily recognized by the shape of the genital segment and the single strong spine on the lst basal segment of the 4th leg. E. propria is, 
as suggested by Vervoort (1963), the male of E. truncata. The following table illustrates the distribution and size variation:

\begin{tabular}{|c|c|c|c|c|c|}
\hline \multirow[t]{2}{*}{ Author } & & \multirow{2}{*}{ Locality } & \multirow{2}{*}{ Depth } & \multicolumn{2}{|c|}{ Length (mm) } \\
\hline & & & & q & o \\
\hline ESTERLY, & 1911 & San Diego region & $0-150 \mathrm{fms}$. & 6.6 & 5.6 \\
\hline WOLFENDEN, & 1911 & South Atlantic & $0-3000 \mathrm{~m}$ & $5.6-6.0$ & - \\
\hline WITH, & 1915 & North Atlantic & $0-300 \mathrm{~m}$ & 5.66 & 5.3 \\
\hline SARS, & 1925 & North Atlantic & $0-1000 \mathrm{~m}$ & 6.20 & - \\
\hline SEWELL, & 1947 & Arabian Sea & $0-400 \mathrm{~m}$ & $5.23-5.50$ & - \\
\hline VERVOORT, & 1949 & Malay Archipelago & $0-60 \mathrm{~m}$ & $5.55-6.05$ & - \\
\hline TANAKA, & 1957 & Izu region & $200-400 \mathrm{~m}$ & 6.19 & - \\
\hline $\begin{array}{r}\text { TANAKA and } \\
\text { (unl }\end{array}$ & $\begin{array}{l}\text { OMоRI } \\
\text { uubl.) }\end{array}$ & Izu region & $0-920 \mathrm{~m}$ & $5.80-6.40$ & 5.10 \\
\hline Present record & & Off Peru and Chile & $0-300 \mathrm{fms}$. & $5.25-5.35$ & 4.92 \\
\hline
\end{tabular}

\section{Euchirella venusta GIESBRECHT, 1888}

(Fig. 10, a-i)

Euchirella vanusta Giesbrecht, 1892, p. 233, pl. 15, fig. 19, pl. 36, fig. 21; Sewelt, 1947, p. 85, fig. 18; Vervoort, 1949, p. 20, fig. 20; Wilson, 1950, p. 226, pl. 9, figs. 95-97; TANAKA, 1957, p. 182, fig. 47, a-e; GRICE, 1962, p. 194, pl. 9, figs. 14-25; OMORI, 1965, p. 64, figs. 22-24; OWRE and Foyo, 1967, p. 48, figs. 277-280.

Occurrence: U.S.N.M. No. 67135, 2 ad. 우, 2 ad. ơ; U.S.N.M. No. 67137, 1 ad.

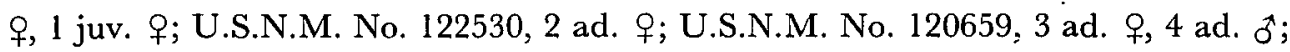
U.S.N.M. No. 122531,22 ad. $q$.

Descriptive notes: Female, $4.20-4.90 \mathrm{~mm}$. The cephalothorax and abdomen are in the proportional lengths as 79 to 21 . The head is fused with the lst thoracic segment. The forehead is rounded, and there is no trace of a crest. The rostrum is slender and depressed; it is directed downwards.

The abdominal segments and furca are in the following proportional lengths:

\begin{tabular}{|c|c|c|c|c|c|}
\hline & $1-2$ & 3 & 4 & 5 & furca \\
\hline
\end{tabular}

The genital segment agrees well with that described by Sewell (1947) and VervoorT (1949). In dorsal view the segment has a round swelling on the left lateral margin, and a tubercle on the right lateral margin. The swelling on the left margin in some specimens is not smooth but irregular in outline. According to SEwell (1947), the genital and 3rd segments are each armed with a row of spinules on the distal margin. In the present material some specimens have no spinules on the genital segment.

The lst antenna reaches a little beyond the end of the furca. In the 2 nd antenna 
the distal segment of the endopod carries 5 setae on the outer lobe, and 4 setae on the inner lobe. The mandible has the exopod and endopod of about the same length. In the lst maxilla the outer lobe is furnished with 6 setae; the exopod with 11 setae; the endopod with 4 setae; the 2nd basal segment with 3 setae; the 3 rd inner lobe with 2 setae and a small process; the 2 nd inner lobe with 4 setae; the lst inner lobe with 13 setae. The maxilliped has the basal segments of about equal length.

In the 4th leg the inner margin of the lst basal segment is furnished with 2
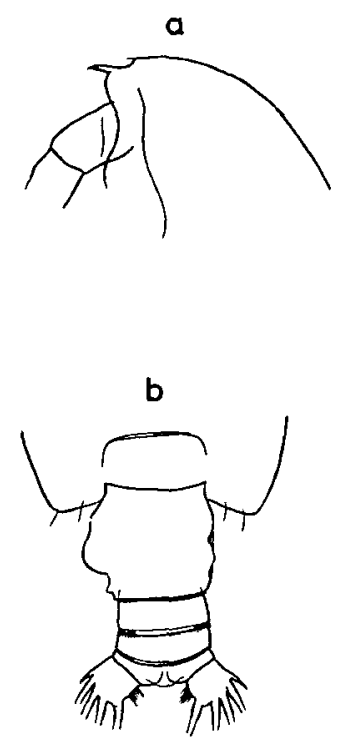

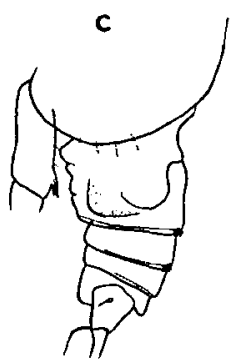

d

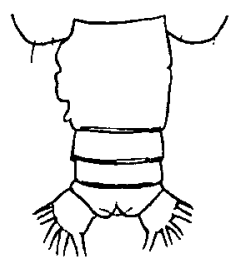

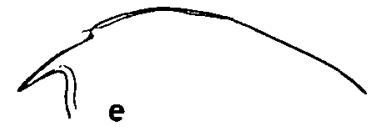
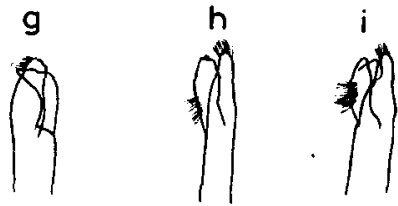

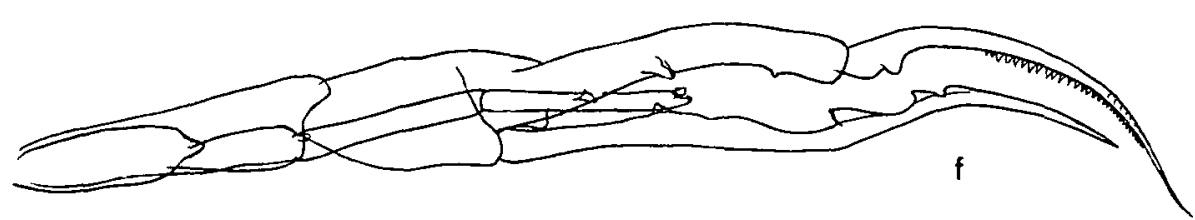

Fig. 10. Euchirella venusta Giesbrecht, female: $a$, head, lateral view; $b$, last thoracic segment and abdomen, dorsal view; $c$, last thoracic segment and abdomen, lateral view; $d$, abdomen, dorsal view of another specimen. male: $e$, head, lateral view; $f, 5$ th pair of legs; $g$, left 5 th leg, distal segment of exopod; $h$, another view of the same; $i$, the same, another specimen.

spines of about equal length which reach the distal margin of the lst basal segment.

Male, 3.57-4.16 $\mathrm{mm}$. The cephalothorax and abdomen are in the proportional longths as 77 to 23 . The forehead is rounded and is devoid of any crest. The rostrum is slender and depressed, directing downwards.

The abdominal segments and furca are in the following proportional lengths:

$\begin{array}{lrrrrrr}\text { segment } & 1 & 2 & 3 & 4 & 5 & \text { furca } \\ & 29 & 29 & 16 & 14 & 2 & 10\end{array}=100$


In the 1st antenna the various segments have the following proportional lengths which agree fairly well with those given by SEwELL (1947):

\begin{tabular}{|c|c|c|c|c|c|c|c|c|c|c|c|c|c|c|}
\hline seg & nent & 1 & & 3 & 4 & 5 & 6 & 78 & $8-9$ & 10 & 11 & $12-13$ & 14 & 15 \\
\hline & left & 66 & 44 & 21 & 18 & 21 & 21 & 24 & 36 & 24 & 27 & 69 & 47 & 63 \\
\hline 6 & 17 & 18 & 19 & 20 & 21 & 22 & 23 & 24-25 & & & & & & \\
\hline 69 & 69 & 66 & 66 & 57 & 48 & 54 & 45 & 45 & $=10$ & 000 & & & & \\
\hline
\end{tabular}

In the 2nd antenna the distal segment of the endopod is furnished with 6 setae on the outer lobe and 7 setae on the inner lobe. In the 1st maxilla the 1st to 3rd inner lobes are much reduced; the outer lobe has 5 and the exopod has 11 setae.

The 1st leg has an usual structure: the 1st segment of the exopod is provided with 2 minute spines on the outer margin. In the 5th pair of legs the distal margin of the 2nd basal segment of the left leg reaches the distal margin of the 1st basal segment of the right leg. The exopod of the left leg is slender; the 2 segments are of equal length: the distal end of the 2nd segment of the exopod exceeds the proximal process on the outer margin of the endopod of right leg; the claw is as shown in the figures which agrees with that figured by Sewel (1947). In the right leg the proportional lengths of the 2 basal segments are as 57 to 34 ; the 1st segment of the exopod is furnished with 4 processes on the inner margin, of which the lst one is rounded, the 2 nd one is sharply pointed, the 3 rd is large and bluntly pointed, and the 4th is small. The endopod of the right leg has a triangular process on the outer margin at the level of the 3 rd prominence on the inner margin of the 1st segment of the exopod.

Remarks: E. tanseii OMORI (1965) described from Sagami Bay is very closely related to $E$. venusta. However, in $E$. tanseii there is no tubercle on the right lateral margin of the genital segment and both outer and inner lobes of the distal segment of the endopod of the 2nd antenna are furnished with 6 setae each.

Some records of the distribution and variation in length of $E$. venusta are summerized as follows:

\begin{tabular}{llllcc} 
Author & & Locality & Depth & \multicolumn{2}{c}{ Length (mm) } \\
& & & $q$ & $\delta$ \\
SEWELL, $\quad 1947$ & Arabian Sea & $0-500 \mathrm{~m}$ & 4.38 & 3.80 \\
VERVOORT, 1949 & Malay Archipelago & $0-60 \mathrm{~m}$ & $4.25-4.60$ & - \\
WILSON, $\quad 1950$ & Off Mexico & $0-300 \mathrm{fms}$. & - & - \\
TANAKA, $\quad 1957$ & Suruga Bay & $0-1000 \mathrm{~m}$ & 4.88 & - \\
GRICE, $\quad 1962$ & Equatorial Pacific & $0-169 \mathrm{~m}$ & $4.37-4.84$ & 3.80 \\
TANAKA and OMORI & Izu region & $0-360 \mathrm{~m}$ & $4.40-4.85$ & - \\
\multicolumn{2}{r}{$\quad$ (unpubl.) } & & & & \\
Present record & Western Pacific & - & $4.20-4.90$ & $3.57-4.16$
\end{tabular}




\section{REFERENGES}

BrodsKy, K.A. 1950. Copepoda Calanoida of the far eastern seas of USSR and the polar basin. Descriptive list of Fauna of USSR. Izdav. Zool. Inst. Akad. Nauk, SSSR, vol. 35, pp. 1-442. (In Russian)

Davis, C.C. 1949. The pelagic Copepoda of the northeastern Pacific Ocean. Univ. Washington Publ. Biol., vol. 14, pp. 1-118.

Esterly, C.O. 1905. The pelagic Copepoda of the San Diego region. Univ. California Publ. Zool., vol. 2, pp. 113-233.

- 1906. Additions to the copepod fauna of the San Diego region. Ibid., vol. 3, pp. 53-93.

- 1911. Third report on the Copepoda of the San Diego region. Ibid., vol. 6, pp. 313-353.

Farran, G.P. 1929. Copepoda. Nat. Hist. Rept. Terra Nova Exped., Zool., vol. 8, no. 3, pp. 203-306.

Giesbrecht, W. 1892. Systematik und Faunistik der Pelagischen Copepoden des Golfes von Neapel. Fauna u. Flora Golf. Neapel, vol. 19, pp. 1-831, pls. 1-54.

Grice, G.D. 1962. Calanoid copepods from equatorial waters of the Pacific Ocean. Fishery Bull. Fish Wildl. Serv., vol. 61, pp. 167-246.

Grice, G.D. and K. Hulsemann 1967. Bathypelagic calanoid copepods of the western Indian Ocean. Proc. U.S. Nat. Mus., vol. 122, no. 3583, pp. 1-67.

Morr, T. 1937. The pelagic Copepoda from the neighbouring waters of Japan. Tokyo. $150 \mathrm{p}$.

OMorı, M. 1965. A new species of Euchirella (Copepoda) from Sagami Bay, middle Japan. J. Oceanogr. Soc. Japan, vol. 21, pp. 60-65.

Owre, H.B. and M. Foyo 1967. Copepods of the Florida Current. Fauna Caribaea, no. 1, Crustacea, part 1, Copepoda, $137 \mathrm{p}$.

SARS, G.O. 1925. Copépodes particulièrement bathypélagiques provenant des campagnes scientifiques du Prince Albert ler de Monaco. Résult. Camp. Sci. Monaco, vol, 69, pp. 1-408, pls. 1-127 (1924).

Scotr, A. 1909. The Copepoda of the Siboga Expedition. 1. Free-swimming, littoral and semiparasitic Copepoda. Siboga Exped., monogr. 29a, pp. 1-323.

Sewel., R.B.S. 1929 and 1932 . The Copepoda of Indian Seas. Mem. Indian Mus., vol. 10, pp. 1-221 (1929); pp. 223-407 (1932).

- 1947. The free-swimming planktonic Copepoda. Systematic account. Sci. Rep. J. Murray Exped., vol. 8, pp. 1-303.

Tanaka, O. 1957. The pelagic copepods of the Izu region, middle Japan. Systematic account IV. Family Aetideidae (part 2). Publ. Seto Mar. Biol. Lab., vol. 6, pp. 169-207.

TANAKA, O. and M. OMORI 1968. Additional report on calanoid copepods from the Izu region. I. Euchaeta and Pareuchaeta. Ibid., vol. 16, pp. 219-261.

Vervoort, W. 1949 Some new and rare Copepoda Calanoida from East Indian Scas. Zool. Verh., Leiden, no. 5, pp. 1-53.

- 1957. Copepods from Antarctic and sub-antarctic plankton samples. Rep. B.A.N.Z. Antarct. Res. Exped., ser. B, vol. 3, pp. 1-160.

- 1963. Pelagic Copepoda, part I. Copepoda Calanoida of the families Calanidae up to and including Euchaetidae. Atlantide Rept., no. 7, pp. 77-194.

Wilson, C.B. 1942. The copepods of the plankton gathered during the last cruise of the Carnegie. Scientific results of cruise VII of the Carnegie during 1928-1929 under command of Capt. J.P. Ault. Carnegie Inst. of Washington Publ. 536, pp. 1-237.

- 1950. Copepods gathered by the U.S. Fisheries Steamer Albatross from 1887 to 1909, chiefly in the Pacific Ocean. Bull. U.S. Nat. Mus. 100, vol. 14, pp. 141-441.

WrTH, C. 1915. Copepoda I, Calanoida Amphascandria. Dan. Ingolf Exped., vol. 3, pt. 4, pp. 1-260. Wolfenden, R.N. 1911. Die marinen Copepoden der Deutschen Südpolar Expedition 1901-1903, II. Die pelagischen Copepoden der Westwinddrift und des südlichen Eismeeres. Dtsch. Südpolar Exped., vol. 12, pp. 181-380, pls. 22-41. 


\section{Appendix-table}

-Specimens of the Wilson Collection sent from the Smithsonian Institution and corrected identification of the species.

\begin{tabular}{|c|c|c|c|c|c|c|}
\hline $\begin{array}{c}\text { Original } \\
\text { identification }\end{array}$ & $\begin{array}{l}\text { Original } \\
\text { U.S.N.M. } \\
\text { cat. No. }\end{array}$ & Locality & Collector & $\begin{array}{l}\text { Corrected } \\
\text { identification }\end{array}$ & $\begin{array}{l}\text { No. of } \\
\text { Specimens }\end{array}$ & $\begin{array}{l}\text { New } \\
\text { U.S.N.M. } \\
\text { cat. No. }\end{array}$ \\
\hline \multirow[t]{10}{*}{ Euchirella bella } & 67073 & $\begin{array}{c}\text { Between Easter and } \\
\text { Galapagos Is. }\end{array}$ & $\begin{array}{l}\text { Albatross } \\
\text { Sta. } 4700\end{array}$ & E. bella & 229 & 67073 \\
\hline & 67074 & Off Peru & $\begin{array}{l}\text { Albatross } \\
\text { Sta. } 4665\end{array}$ & E. bella & 1 우 & 67074 \\
\hline & 67075 & $?$ & Albatross & E. bella & 179 & 6707.5 \\
\hline & 67085 & $?$ & Albatross & E. bella & 10 & 67085 \\
\hline & 67122 & Between Easter and & Albatross & E. bella & 10 & 67122 \\
\hline & & Galapagos Is. & Sta. 4700 & E. amoena & $5 \delta^{\pi}$ & 122507 \\
\hline & 67123 & Off Chile & Albatross & E. bella & 19 & 67123 \\
\hline & & & Sta. $\quad 15$ & & & \\
\hline & 67124 & $\begin{array}{c}\text { Panama and Easter } \\
\text { to Galapagos Is. }\end{array}$ & $\begin{array}{l}\text { Albatross } \\
\text { Stas. } 4638 \\
\text { and } 4716\end{array}$ & E. bella & $49,3 \delta$ & 67124 \\
\hline & 67125 & Off Peru & $\begin{array}{l}\text { Albatross } \\
\text { Sta. } 4667\end{array}$ & E. bella & $1 ㅇ$ & 67125 \\
\hline \multirow[t]{9}{*}{ Euchirella bitumida } & 70313 & Off California & $\begin{array}{l}\text { Albatross } \\
\text { Sta. } 4757\end{array}$ & E. curticauda & $2 q$ & 70313 \\
\hline & 70314 & Off Peru & Albatross & Neocalanus robustior & 1 우 & 122533 \\
\hline & & & Sta. 4680 & Chirundinella cara & $1 \delta$ & 70314 \\
\hline & 70315 & $\begin{array}{l}\text { Off British } \\
\text { Columbia }\end{array}$ & $\begin{array}{l}\text { Albatross } \\
\text { Sta. } 4758\end{array}$ & E. bitumida & 10 & 70315 \\
\hline & 73897 & Pacific & Albatross & $E$. bella & $1 q$ & 73897 \\
\hline & & & & E. galeata & $4 ㅇ, 11 \sigma^{\circ}$ & 122518 \\
\hline & & & & E. maxima & $1 q, 2 \pi$ & 122524 \\
\hline & & & & Undeuchaeta magma & 19 & 122537 \\
\hline & & & & Scottocalanus infrequens & ns $1 \%$ & 122751 \\
\hline \multirow[t]{13}{*}{ Euchirella galeata } & 67078 & Off Central America & $\begin{array}{l}\text { Albatross } \\
\text { Sta. } 4611\end{array}$ & E. galeata & $3 q$ & 67078 \\
\hline & 67128 & Between Peru and & Albatross & E. galeata & 1 운 & 67128 \\
\hline & & Galapagos Is. & Sta. 4652 & $\begin{array}{l}\text { E. grandicornis } \\
\text { Chirundinella cara }\end{array}$ & 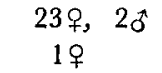 & $\begin{array}{l}123606 \\
122503\end{array}$ \\
\hline & 67129 & $\begin{array}{l}\text { Between Peru and } \\
\text { Easter I. }\end{array}$ & $\begin{array}{l}\text { Albatross } \\
\text { Sta. } 4697\end{array}$ & E. grandicornis & 57 우, $2 \delta$ & 67129 \\
\hline & 67130 & Off Peru & $\begin{array}{l}\text { Albatross } \\
\text { Sta. } 4664\end{array}$ & E. grandicornis & 8 우 & 67130 \\
\hline & 70734 & Off Peru & $\begin{array}{l}\text { Albatross } \\
\text { Sta. } 4679\end{array}$ & E. grandicornis & 1 오 $10 \hat{\alpha}$ & 70734 \\
\hline & 73900 & Pacific & Albatross & E. galeata & 60 우 & 73900 \\
\hline & & & & E. venusta & 29 & 122530 \\
\hline & & & & Lophothrix frontalis & $1 \sigma^{\star}$ & 122532 \\
\hline & 73901 & Pacific & Albatross & E. galeata & 43 아 $5 \widehat{\delta}$ & 73901 \\
\hline & 74392 & China Sea & Albatross & E. galeata & 19 & 74392 \\
\hline & & & Sta. 5320 & E. bitumida & 19 & 122513 \\
\hline & & & & E. maxima & 19 & 122525 \\
\hline
\end{tabular}




\begin{tabular}{|c|c|c|c|c|c|c|}
\hline $\begin{array}{c}\text { Original } \\
\text { identitication }\end{array}$ & $\begin{array}{l}\text { Original } \\
\text { U.S.N.M. } \\
\text { cat. No. }\end{array}$ & Locality & Collector & $\begin{array}{l}\text { Corrected } \\
\text { identification }\end{array}$ & $\begin{array}{l}\text { No. of } \\
\text { Specimens }\end{array}$ & $\begin{array}{l}\text { New } \\
\text { U.S.N.M. } \\
\text { cat. No. }\end{array}$ \\
\hline & & & & $\begin{array}{l}\text { Gaetanus minispinus, } \\
\text { n. sp. }\end{array}$ & 19 & 122750 \\
\hline & & & & Chirundina streetsi & 19 & 122505 \\
\hline \multirow[t]{4}{*}{ Euchirella grandicornis } & is 67131 & Between Peru and & Albatross & E. grandicornis & 1 우 & 67131 \\
\hline & & Easter I. & Sta. 4681 & E. maxima & $10^{*}$ & 122460 \\
\hline & 67081 & & Albatross & E. messinensis indica & 49 & 67081 \\
\hline & & & & E. bella & $10^{*}$ & 120653 \\
\hline \multirow[t]{26}{*}{ Euchirella messinensis } & s 67132 & $\begin{array}{c}\text { Between Galapagos } \\
\text { and Tuamotu Is. }\end{array}$ & $\begin{array}{l}\text { Albatross } \\
\text { Sta. } 4732\end{array}$ & E. messinensis indica & 29 & 67132 \\
\hline & 70318 & Off Peru & Albatross & E. bella & $10^{*}$ & 70318 \\
\hline & & & Sta. 4679 & Gaidius sp. & 19 & - \\
\hline & & & & ? Gaetanus armiger & $10 \pi$ & 122749 \\
\hline & 70389 & Off Equador & $\begin{array}{l}\text { Albatross } \\
\text { Sta. } 4652\end{array}$ & E. messinensis indica & $10 \pi$ & 70389 \\
\hline & 70390 & Off Equador & $\begin{array}{l}\text { Albatross } \\
\text { Sta. } 4638\end{array}$ & E. bella & $10^{\star}$ & 70390 \\
\hline & 73645 & Off Philippines & Albatross & E. orientalis & $10^{*}$ & 122516 \\
\hline & & & Sta. 5785 & E. pulchra & 1 우 & 73645 \\
\hline & & & & Scaphocalanus magnus & 1 우 & 122534 \\
\hline & 73904 & Pacific & Albatross & $\begin{array}{l}\text { E. acuta, n. sp. } \\
\text { (paratypes) }\end{array}$ & $3 \delta^{*}$ & 120661 \\
\hline & & & & E. messinensis indica & $3 \%, 2 \delta^{\circ}$ & 73904 \\
\hline & & & & E. orientalis & $160^{*}$ & 120660 \\
\hline & & & & E. pulchra & 4 우, 3今 & 120658 \\
\hline & & & & E. venusta & 3 ㅇ, $40^{\circ}$ & 120659 \\
\hline & 79512 & Bahamas & Bache Sta. & E. messinensis & $14 \%, 2 \pi$ & 79512 \\
\hline & & & 10210 & E. curticauda & $10 \hat{~}$ & 122515 \\
\hline & & & & E. galeata & 18 & 122519 \\
\hline & & & & E. rostrata & 19 & 122527 \\
\hline & & & & Chirundina streetsi & $39,1 \%$ & 122506 \\
\hline & & & & Undeuchaeta plumosa & 3 우 & 122538 \\
\hline & & & & Scottocalanus securifrons & $n s 1$ 우, 10 & 122536 \\
\hline & 80216 & Off Chile & Carnegie & E. amoena & $10^{*}$ & 120655 \\
\hline & & & Sta. 64 & E. bella & 19 & 80216 \\
\hline & & & & E. messinensis indica & $10^{*}$ & 120656 \\
\hline & & & & E. orientalis & 19 & 120654 \\
\hline & & & & E. truncata & $10^{\star}$ & 120657 \\
\hline \multirow[t]{9}{*}{ Euchirella pulchra } & 67079 & $\begin{array}{l}\text { Between Easter and } \\
\text { Galapagos Is. }\end{array}$ & $\begin{array}{l}\text { Albatross } \\
\text { Sta. } 4700\end{array}$ & E. pulchra & 29 & 67079 \\
\hline & 67080 & $9^{\circ} 02^{\prime} \mathrm{S}, 123^{\circ} 20^{\prime} \mathrm{W}$ & $\begin{array}{l}\text { Albatross } \\
\text { Sta. } 4740\end{array}$ & E. pulchra & 49 & 67080 \\
\hline & 67133 & Off SE. Alaska & Albatross & \multicolumn{3}{|l|}{ Wilsonidius alaskaensis } \\
\hline & & & Sta. 4750 & n. gen., n. sp. & 19 & 67133 \\
\hline & 67134 & Between Peru and & Albatross & E. amoena & 1 우 & 122508 \\
\hline & & Easter I. & Sta. 4681 & E. bella & 19 & 67134 \\
\hline & 73905 & Off Philippines & Albatross & E. pulchra & 89 & 73905 \\
\hline & & & Stas. 5120 & E. curticauda & 19 & 122514 \\
\hline & & & $\begin{array}{l}5190, \text { and } \\
5231\end{array}$ & E. messinensis indica & 29 & 122522 \\
\hline
\end{tabular}




\begin{tabular}{|c|c|c|c|c|c|c|}
\hline $\begin{array}{c}\text { Original } \\
\text { identification }\end{array}$ & $\begin{array}{l}\text { Original } \\
\text { U.S.N.M. } \\
\text { cat. No. }\end{array}$ & Locality & Collector & $\begin{array}{c}\text { Coorrected } \\
\text { identification }\end{array}$ & $\begin{array}{c}\text { No. of } \\
\text { Specimens }\end{array}$ & $\begin{array}{c}\text { New } \\
\text { U.S.N.M. } \\
\text { cat. No. }\end{array}$ \\
\hline & . & & & E. orientalis & 1 우 & 122517 \\
\hline & & & & E. venusta & 22 우 & 122531 \\
\hline & & & & Chirundina indica & $1 \delta^{*}$ & 122504 \\
\hline & & & & Scottocalanus rotundat & lus $1 \delta$ & 122535 \\
\hline & 80127 & Off Maryland & Carnegie & E. amoena & $1 \hat{\delta}$ & 122510 \\
\hline & & & Sta. 1 & E. rostrata & 7 앙 & 80217 \\
\hline & & & & Undinula vulgaris & 19 & 122539 \\
\hline \multirow[t]{14}{*}{ Euchirella venusta } & 67084 & $\begin{array}{l}\text { SW. of Central } \\
\text { America }\end{array}$ & $\begin{array}{l}\text { Albatross } \\
\text { Sta. } 4605\end{array}$ & E. bella & 7 웅 & 67084 \\
\hline & 67135 & Between Peru and & Albatross & E. venusta & 2 우, $20^{x}$ & 67135 \\
\hline & & Easter I. & Sta. 4679 & $\begin{array}{c}E . \text { acuta, n, sp. } \\
\text { (holotype) }\end{array}$ & 10 & 122747 \\
\hline & & & & (paratypes) & 29 & 122748 \\
\hline & & & & E. amoena & 10 & 122509 \\
\hline & & & & E. bella & $10 ㅇ, 2 \delta$ & 122511 \\
\hline & & & & E. maxima & $1 \sigma^{*}$ & 122523 \\
\hline & & & & E. messinensis indica & 2 우 & 122521 \\
\hline & & & & E. rostrata & 1 우 & 122526 \\
\hline & & & & E. truncata & 29 & 122528 \\
\hline & 67136 & Off Chile & Albatross & E. bella & $10 \hat{~}$ & 67136 \\
\hline & & & Sta. SF 15 & E. truncata & 2 우 & 122529 \\
\hline & 67137 & Off Peru & Albatross & E. verusta & 29 & 67137 \\
\hline & & & Sta. 4655 & E. bella & $1 \%$ & 122512 \\
\hline
\end{tabular}

